\title{
Technology Development Needs for High Temperature Process Heat
}
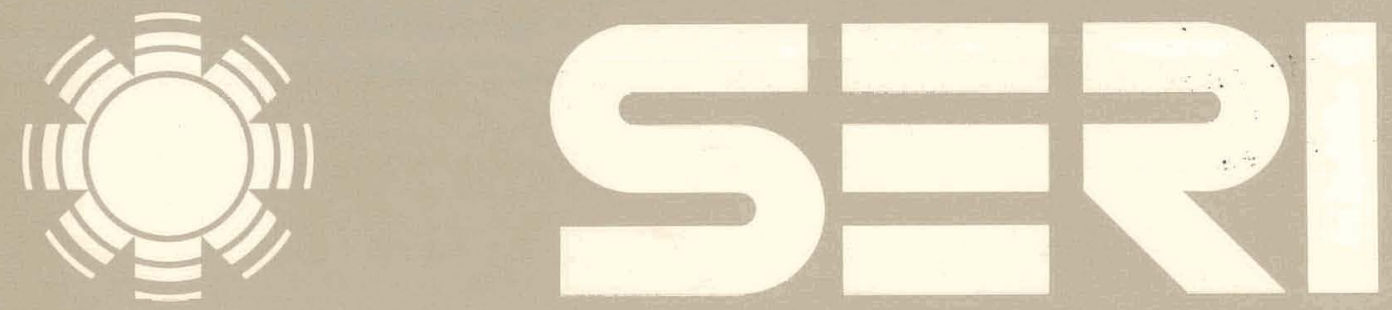

Robert J. Copeland 


\section{DISCLAIMER}

This report was prepared as an account of work sponsored by an agency of the United States Government. Neither the United States Government nor any agency Thereof, nor any of their employees, makes any warranty, express or implied, or assumes any legal liability or responsibility for the accuracy, completeness, or usefulness of any information, apparatus, product, or process disclosed, or represents that its use would not infringe privately owned rights. Reference herein to any specific commercial product, process, or service by trade name, trademark, manufacturer, or otherwise does not necessarily constitute or imply its endorsement, recommendation, or favoring by the United States Government or any agency thereof. The views and opinions of authors expressed herein do not necessarily state or reflect those of the United States Government or any agency thereof. 


\section{DISCLAIMER}

Portions of this document may be illegible in electronic image products. Images are produced from the best available original document. 


\section{NOTICE}

This report was prepared as an account of work sponsored by an agency of the United States Government. Neither the United States nor any agency thereof, nor any of their employees, makes any warranty, expressed or implied, or assumes any legal liability or responsibility for any third party's use or the results of such use of any information, apparatus, product, or process disclosed in this report, or represents that its use by such third party would not infringe privately owned rights. 
SERI/TR-35-047

Distribution :

See last page

$s$

\section{TECHNOLOGY DEVELOPMENT NEEDS FOR HIGH TEMPERATURE PROCESS HEAT}

Technical Repurt

Robert J. Copeland

August 1978

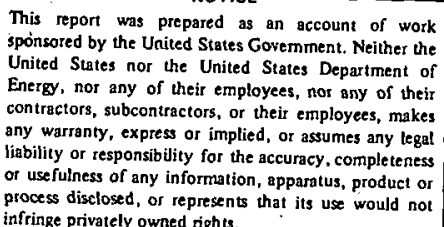

This report was prepared as an account of work sponsored by the United States Govemment. Neither the United States nor the United States Department of Energy, nor any of their employes, Deparment of contractors, subcontractors or any warranty, exprese or inplo en liability or responsibility for the or assumes any legal or use fulness of any informetion, appan, conpleteness process disclosed, or represents the its weduet or infringe privately or represents that its use would not

\section{SOLAR ENERGY RESEARCH INSTITUTE \\ 1536 Cole Boulevard Golden, Colorado 80401}

A Division of Midwest Research Institute

Prepared for the

U.S. Department of Energy

Division of Solar Technology

Under Contract No. EG-77-C-01-4042 
This report is partial documentation on SERI Task 3505, "High Temperature Process Heat," initiated December 1, 1977. This report presents the analysis data of the task. A program strategy was also prepared and is documented separately.

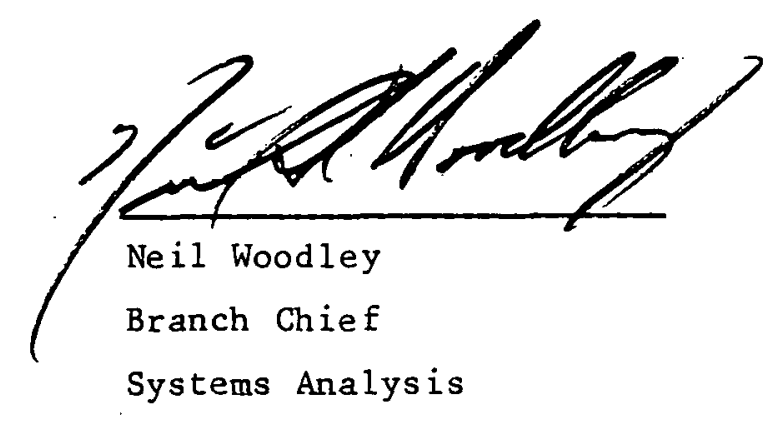

Approved for:

SOLAR ENERGY RESEARCH INSTITUTE

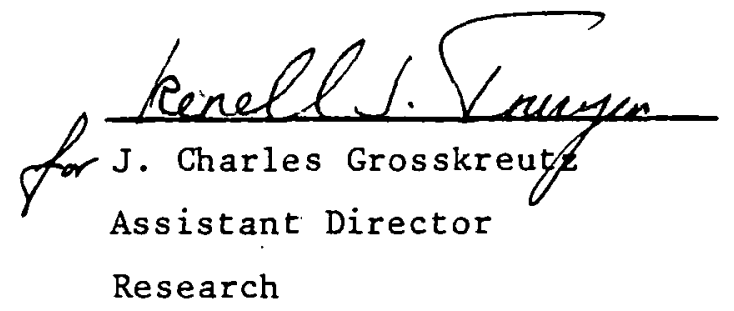


I: Introduction . . . . . . . . . . . . . 1

A. Objectives . . . . . . . . . . . . . . . . 1
B. Approach . . . . . . . . . . . . . . . 1

II. Mission Analysis . . . . . . . . . . 3

A. Review of Previous Studies... . . . . 3

B. Target Industries for High Temperature Process Heat. . . . . . . . . . . . 8

C. A Candidate Industry for Early Emphasis . . . . . . . . . . 10

D. Candidate Solar Collectors . . . . . . 10

III. A Preliminary Evaluation of the Potential for Solar-Thermal Process heat in Petroleum Refining. . . . . . . . . . . . . 16

A. Objective. . . . . . . . . . . . 16

B. Refinery Energy Requirements. . . . . . 16

C. Solar-Thermal Hydrogen Production. . . . . 28

IV. Development Needs. . . . . . . . . . . . . 33

A. Technology Development Needs....... 33

B. What is Economic?. . . . . . . . . 35

V. References . . . . . . . . . . . 37

Appendix Availability and Performance Contour Maps for

Tracking Collector Systems in the

United States. . . . . . . . . . . . . . . A-1 


\section{LIST OF TABLES}

Number

Page

II-1

Industrial Energy Consumption by

Market Sector and Energy Use . . . . . . 4

I I - 2

Comparison of Battelle, ITC, and MDAC

Process Heat Surveys .. . . . . . . 5

II -3

Recent Market Penetration Predictions for

Process Heat .. . . . . . . . . . . 7

II -4

Potential Applications of Solar Thermal

High Temperature Process Heat. . . . . . . 9

I I I - I

Refining Fuel and Energy Sources . . . . 17

III-2

U. S. Refinery Size Distribution . . . . . 19

III -3

Refining Usage of Process Heat . . . . . 22

II I 4

Shell oil Refineries

(West of the Mississippi). . . . . . . . 27

III -5

Thermochemistry of the Water-Gas Reaction. . 31 
Number

Page

$I I-1$

A Summary of Properties of Typical

Solar Collectors. . . . . . . . . . .

$I I-2$

Current Efficiencies of Solar Collectors.

14

III-1

Process Flow Diagram of Petroleum

Refining Industry . . . . . . . . . .

II I-2

Approximate Size of a Solar-Thermal Field

for a Nominal Refinery $(120,000 \mathrm{~B} / \mathrm{CD})$. . .

$\operatorname{III}-3$

Siting of a Solar Field for the Humble Baytown Refinery. . . . . . . . . . . •

III -4

$\mathrm{H}_{2}$ Production Approach. . . . . . . . . 


\section{ABSTRACT}

This study investigated the potential utilization of high temperature solar thermal process heat. The objective was to identify process specific problems and development needs. One industry was reviewed in some detail, and one of many candidate technologies was also investigated. Costs, land availability, and energy transfer were the key problem areas. With appropriate development all problems appeared solvable. More detailed evaluations of each large energy user industry were recommended.

The United States utilizes from $12 \%$ to $26 \%$ of all its fuel consumption for process heat. Most of that heat is high temperature (greater than $350^{\circ} \mathrm{F}$ ) representing $10 \%$ to $20 \%$ of all U. S. fuel consumption. If a significant fraction of that market can be supplied by solar thermal energy, clearly a large reduction in imported oil would occur.

The six largest process heat user industries consume about $90 \%$ of all high temperature process heat. These industries are:

- $\quad$ Petroleum Refining
- $\quad$ Cement
- Glass
- Ceramics
- Chemical (inorganic)

Solar thermal concentrating collectors can provide heat at the required temperaturas for these industries.

Technology development needs for utilization of solar-thermal process heat are investigated. The petroleum industry is selected 
as an example industry. Costs, availability of land, and integration problems are some of the key barriers to implementation. A candidate technology utilizing hydrogen for energy transport could solve some of the problems; other candidate technologies are steam and sensible heat transport, direct heating, and chemical heat pipes.

Cost is a major barrier to the use of solar thermal energy in process heat. Currently, the cost of collectors is uneconomically high but is expected to drop in the future. The rapid pay-back time on capital demanded by industry increases the impact of the cost barrier. Solar thermal technology does have unique advantages for industries (e.g., freedom from embargos, curtailments, and strikes). The composite value of solar process heat to the user is still not known. 


\section{INTRODUCTION}

Recent studies $[1,2,3,4]$ have evaluated the use of process heat in the United States. A large potential for solar-thermal process heat exists. This potential market is on the order of $12 \%$ to $26 \%$ of all U. S. fuel consumption. If even a fraction of that market is captured by solar, obviously a significant reduction in imported oil consumption would occur.

The development of solar-thermal technology is proceeding rapidly. For low temperature process heat (less than $350^{\circ} \mathrm{F}, 177^{\circ} \mathrm{C}$ ) flat plate collectors, solar ponds, and line-focusing technologies are being used in process heat experiments [5]. Process heat specific technologies are being developed for those low temperature applications. Parabolic troughs, parabolic dishes, fresnel lens systems, fixed receiver line focus, fixed mirror devices, and central receiver systems are being developed for dispersed and central power systems. Those concentrating collectors are capable of delivering heat at higher temperatures, i.e., suitable for process heat. However, the process heat specific technology development is still in its early stages.

\section{A. OBJECTIVE}

The objective of this SERI task was to identify specific high temperature process heat problems and technology development needs.

\section{B . APPROACH}

The approach to identifying problems and technology development needs is outlined below: 
- Review previous studies on process heat,

- Identify the target industries for high temperature process heat,

- Study one example industry to identify specific problems,

- Illustrate how technology development could solve one or щữe problems,

- Present a program strategy to the Department of Energy (DOE), Office of Energy. Technology (ET).

This report documents the results of the first four items. The presentation to DOE is documented separately [6]. 


\section{MISSION ANALYSIS}

This section presents the identified market potential for solar thermal high temperature process heat. Results of previous studies in process heat are compared and target industries (i.e., largest users) are identified. A single industry is selected for closer study and candidate solar collector technologies are identified.

\section{A. REVIEW OF PREVIOUS STUDIES}

Four previous studies have investigated process heat applications in detail. Battelle and InterTechnology [1, 2] cataloged process heat data by Standard Industrial Classification (SIC) codes. McDonnelI Douglas Astronautics Company (MDAC) [3] identified industrial solar total energy applications. Aerospace [4] identified the significance of process heat in. the nation's economy and began the task of identifying the systems integration problems for high temperature process heat.

Table II-1 presents the utilization of energy in the United States. The industrial use of fuels and electricity is also shown by end use. According to InterTechnology Corp. (ITC) $68.4 \%$ of al1 industrial energy use is process heat. That percentage was assumed by ITC based upon an old study by Stanford Research Institute [7] for 1968. MDAC also surveyed energy use (fuels and electricity) by industry but also used the old stanford data to extrapolate process heat use. Data by Battelle [1] indicate that the use of process heat is much lower; possibly only $40 \%$ of industrial energy is process heat.

Table II-2 presents a comparison of Battelle, ITC, and MDAC data. Both Battelle and ITC account industry process heat utilization by SIC codes of individual companies. MDAC accounted only energy 
TABLE II -1

INDUSTRIAL ENERGY CONSUMPTION BY MARKET SECTOR AND ENERGY USE

Distriblition of Energy Consumption 1 by Market Sector-1971

\begin{tabular}{lrrrr}
$\begin{array}{l}\text { Market } \\
\text { Sector }\end{array}$ & \multicolumn{2}{c}{$\begin{array}{c}\text { Purchased } \\
\text { Fuels }\end{array}$} & \multicolumn{2}{c}{$\begin{array}{c}\text { Purchased } \\
\text { Fuels \& Elec }\end{array}$} \\
\hline & Quads & $\%$ & Quads & $\%$ \\
\hline $\begin{array}{l}\text { Household/ } \\
\text { Comm }\end{array}$ & 14.3 & 20.7 & 17.4 & 30.6 \\
Transport & 17.0 & 24.6 & 17.0 & 29.8 \\
Industrial & 20.3 & 29.6 & 22.6 & 39.7 \\
Elec Gen & 69.0 & 100.0 & 57.0 & 100.0 \\
\hline \multicolumn{1}{l}{ Total } & 69.0 & 100.0 & 57.0 & 100.0 \\
\hline
\end{tabular}

Industrial Energy Use ${ }^{2}$ (\%)

$\begin{array}{lrr}\text { Process Steam } & 40.6 & \\ \text { Direct Process Heat } & 27.8 & 68.4 \%\end{array}$

Electric Drive $\quad 19.2$

Electric Process $\quad 2.8$

$\begin{array}{ll}\text { Feed Stock } & 8.8\end{array}$

Other $\quad 0.8$

Total $\quad 100.00$

1. Source: Energy Conservation in the Manufacturing Section - 1954-1990, Energy and Environmental Analysis, Inc., preparej for the Council on Environmental Quality, November 1974.

2. Source: Analysis of The Economic Potential of Solar Thermal Energy to Provide Industrial Process Heat, InterTechnology Corporation, prepared for the Energy Research and Development Administration Division of Solar Energy, February 1977. (Ref. 2 ) 
TABLE II-2

COMPARISON OF BATTELLE, ITC, AND MDAC PROCESS HEAT SURVEYS

\begin{tabular}{|c|c|c|c|}
\hline \multirow[b]{2}{*}{ Industry Group } & \multicolumn{3}{|c|}{$\begin{array}{l}1974 \text { Identified } / \text { tilization } \\
\text { of Energy }\left(10^{15}\right) \text { Btu/Yr }\end{array}$} \\
\hline & $\begin{array}{c}\text { Battelle } \\
\text { Process Heat } \\
\end{array}$ & $\begin{array}{c}\text { ITC } \\
\text { Process Heat } \\
\end{array}$ & 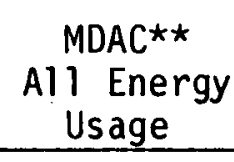 \\
\hline $\begin{array}{l}\text { Chemical arid Allied Products } \\
\text { Primary Metals } \\
\text { Petroleum and Coal Products } \\
\text { Paper and P.1lied Products } \\
\text { Stone, Clay, and Glass Products } \\
\text { Food and Kindred } \\
\text { All Others }{ }^{\star}\end{array}$ & $\begin{array}{l}0.4 \\
1.95 \\
3.11 \\
0.69 \\
1.12 \\
0.70 \\
0.47\end{array}$ & $\begin{array}{l}0.135 \\
3.95 \\
2.54 \\
1.27 \\
0.95 \\
0.36 \\
0.60\end{array}$ & $\begin{array}{l}5.28 \\
4.65 \\
3.30 \\
2.50 \\
2.48 \\
1.96 \\
4.25\end{array}$ \\
\hline Total Identified & 7.87 & 9.81 & 25 \\
\hline $\begin{array}{l}\text { Extrapolated Total } \\
\text { For Process Heat }\end{array}$ & 10.04 & $17.1^{\star \star}$ & $17^{\star \star \star}$ \\
\hline
\end{tabular}

* About $20 \%$ or less of ail process heat.

**Assumes $68.4 \%$ as process heat of 25 Quads fuels consumption based upon Stanford Research Institute Report January 1972. MDAC data are the totals for purchased fuels and electricity for ali purposes. 
usage without separating out the process heat. The MDAC and ITC extrapolated totals for process heat are in agreement since they used the same data base. Battelle shows a much smaller usage of process heat. The difference could be as great as 7Q (in 1974), or a difference of $40 \%$. Battelle's extrapolated total was based upon its estimation of the quantities missed in the survey of individual companies.

The top six industries consume more than 80\% of all process heat in each survey baoc. The top cncrgy uacro arc differcht in the three surveys. Because both the Chemical and Allied products and the Primary Metals industries have a high energy content product, some of the energy account as process heat may actually be chemical energy (e.g., the reduction of iron ore to iron). This effect may be the cause of the differences in the surveys or it may not be. The cause of the variances is unknown. To ensure conservative results, the Battelle data were used as the baseline for SERI's study. Regardless of the data base on process heat, the quantity used by the United states is a very large and significant market.

Table II-3 preacnto the reoulto of two recent marict penetration studies. The two models made cost projections for solar thermal collectors and alternative fuels. MITRE assumed that solar collectors would drop rapidly in price and the alternative fuels would rise rapidly. SRI International assumed relatively high cost solar collectors and continued low cost coal until beyond 2020. The differences in results are predictable. MITRE estimates a very large utilization of solar; SRI International predicts very small market penetration by solar thermal collectors. The true set of future circumstances is not known. Clearly, a large market can be developed in process heat if the appropriate solar collector technology is available at low cost. 
TABLE II-3

RECENT MARKET PENETRATION PREDICTIONS

FOR PROCESS HEAT (ALL TEMPERATURES; CONSTANT 1977 DOLLARS)

\begin{tabular}{|c|c|c|c|c|}
\hline & & 1985 & 2000 & 2020 \\
\hline $\begin{array}{l}\text { MITRE } \\
\text { (SPURR } \\
\text { Me thodology } \\
\text { June 1977) }\end{array}$ & $\begin{array}{l}\text { RTS } \\
\text { NEP } \\
\text { Solar }\end{array}$ & $\begin{array}{l}0.014 \text { Quads } \\
0.024 \text { Quads } \\
\$ 9.00 / \text { MBtu }\end{array}$ & $\begin{array}{l}1.44 \text { Quads } \\
2.02 \text { Quads } \\
\$ 4.50 \mathrm{MBtu}\end{array}$ & $\begin{array}{l}9.77 \text { Quads } \\
13.50 \text { Quads } \\
\$ 4.00 / \text { MBtu }\end{array}$ \\
\hline \multirow[t]{2}{*}{$\begin{array}{l}\text { SRI } \\
\text { International } \\
\text { (Jan. 1978) }\end{array}$} & $\begin{array}{l}\text { Base Case } \\
\text { High Cost } \\
\text { Non-Solar }\end{array}$ & $\begin{array}{l}-0 \text { - Quads } \\
-0 \text { - Quads }\end{array}$ & $\begin{array}{l}-0-\text { Quads } \\
0.2 \text { Quads }\end{array}$ & $\begin{array}{l}0.1 \text { Quads } \\
0.8 \text { Quads }\end{array}$ \\
\hline & Solar & $\$ 13.20 / \mathrm{MBtu}$ & $\$ 10.80 / \mathrm{MBtu}$ & $\$ 9.60 / \mathrm{MBtu}$ \\
\hline
\end{tabular}

Notes:

MITRE: 0 RTS has no solar incentives

- NEP has an additional $10 \%$ investment tax credit

- About $80 \%$ of the collectors are concentrating and about $20 \%$ are $P 1$ anar

- Coal cost at $\$ 3 / \mathrm{MBtu}$ rising to $\$ 5 / \mathrm{MBtu}$ in 2020

SRI: o Assumes coal is available at $\$ 1.80$ to $\$ 1.90 / \mathrm{MBtu}$ through 2020 . 
B. TARGET INDUSTRIES FOR HIGH TEMPERATURE PROCESS HEAT

The best industries for solar thermal process heat are identified in this section. The previous studies have data on both low and high temperature process heat usage. SERI has analyzed the Battelle and ITC data [1,2], industry by industry, and as a function of temperature.

Table II-4 presents the identified utilization by industry and end use temperature. The top users of high temperature process heat are as follows:

Based upon

Battelle Data

1. Petroleum Refining

2. Steel and Iron

3. Cement

4. Glass

5. Ceramics

6. Chcmical (inorganic)
Based upon

ITC

Steel and Iron

Petroleum Refining

Cement

Paper and rulp

Glass

Ceramics

The ranking is according to total process heat utilization. There are significant variations in the order, but the top six inductriec are nearly the sime: rolarly, these industries should be the primo targets for high temperature process heat applications. All types of process heat and temperature ranges are represented in these six industries. Any technology which is developed will. probably be usable in all other industries. 
TABLE II -4

POTENTIAL APPL ICATIONS OF

SOLAR THERMAL HIGH TEMPERATURE PROCESS HEAT

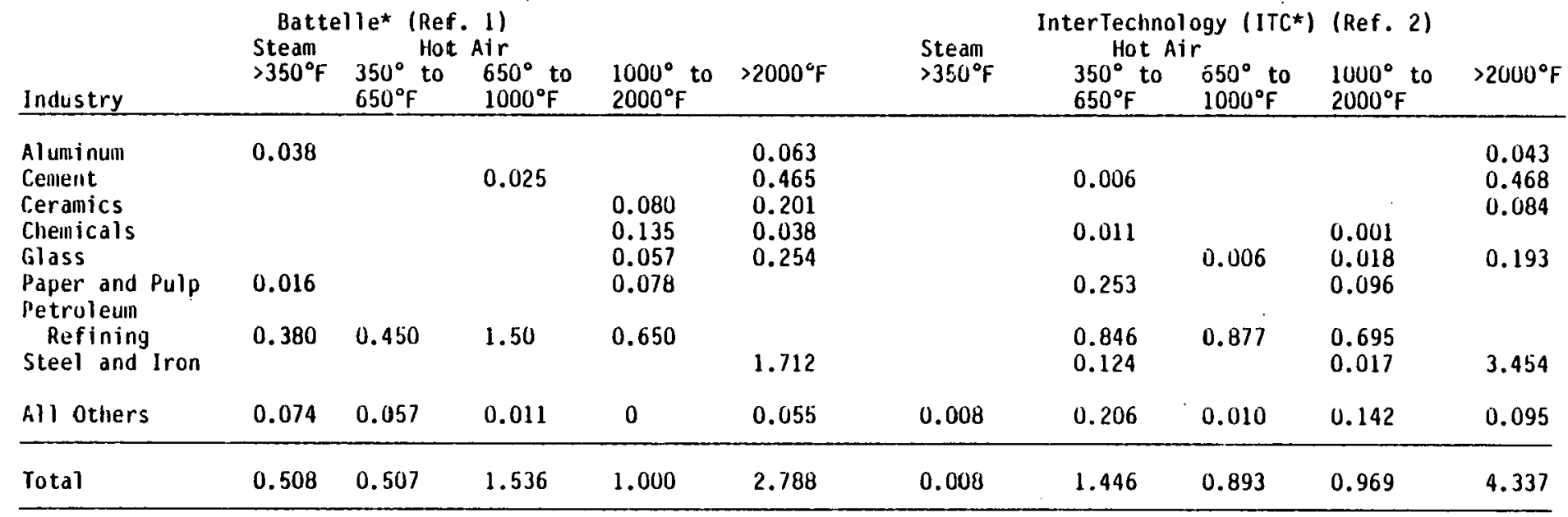

*In $10^{15}$ itu/Yr, 1974 data, identified uses only 


\section{CANDIDATE INDUSTRY FOR EARLY EMPHASIS}

A single industry was selected to identify technology needs. The criteria for the choice were:

- must be one of the top energy users,

- must have a large number of facilities in the southwest (i.e., most probable early use region),

- must require significant process heat and temperatures achievable by current technology solar concentrator.

The petroleum refining industry meets all these criteria. Petroleum refining is either the top or second largest user of process heat. The southwest, particularly Texas and New Mexico, is well known for refineries. All process heat is required at less than $2000^{\circ} \mathrm{F}$ which is achieved by central receiver systems and parabolic dishes. The next section presents data on solar collector systems. Then the initial analysis on the petroleum refining industry is deseribed.

\section{CANDIDATE SOLAR COLLECTORS}

The candidate solar collectors can deliver usable heat at temperatures greater than $350^{\circ} \mathrm{F}\left(177^{\circ} \mathrm{C}\right.$ or $\left.450 \mathrm{~K}\right)$. The types are allgmenter flat plates, line focusing and two-axis tracking point focus collectors. Figure II-l presents the achievable temperatures for each type. The current status of the hardware is as follows: 


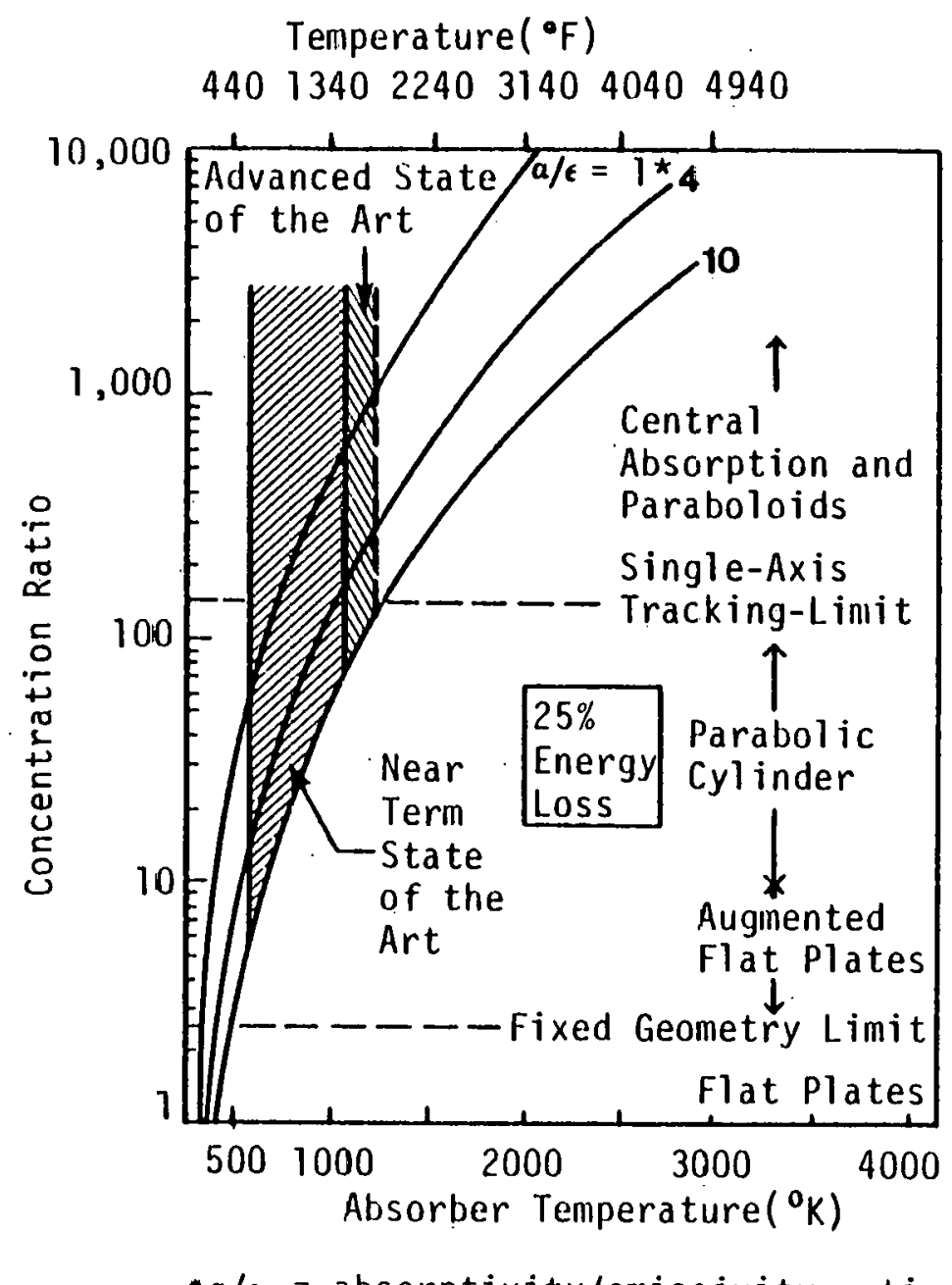

- $a / \epsilon=$ absorptivity/enissivity ratio

Source: Aerospace, Ref. 4

Figure II-1. A Summary of Properties of Typical Solar Collectors 


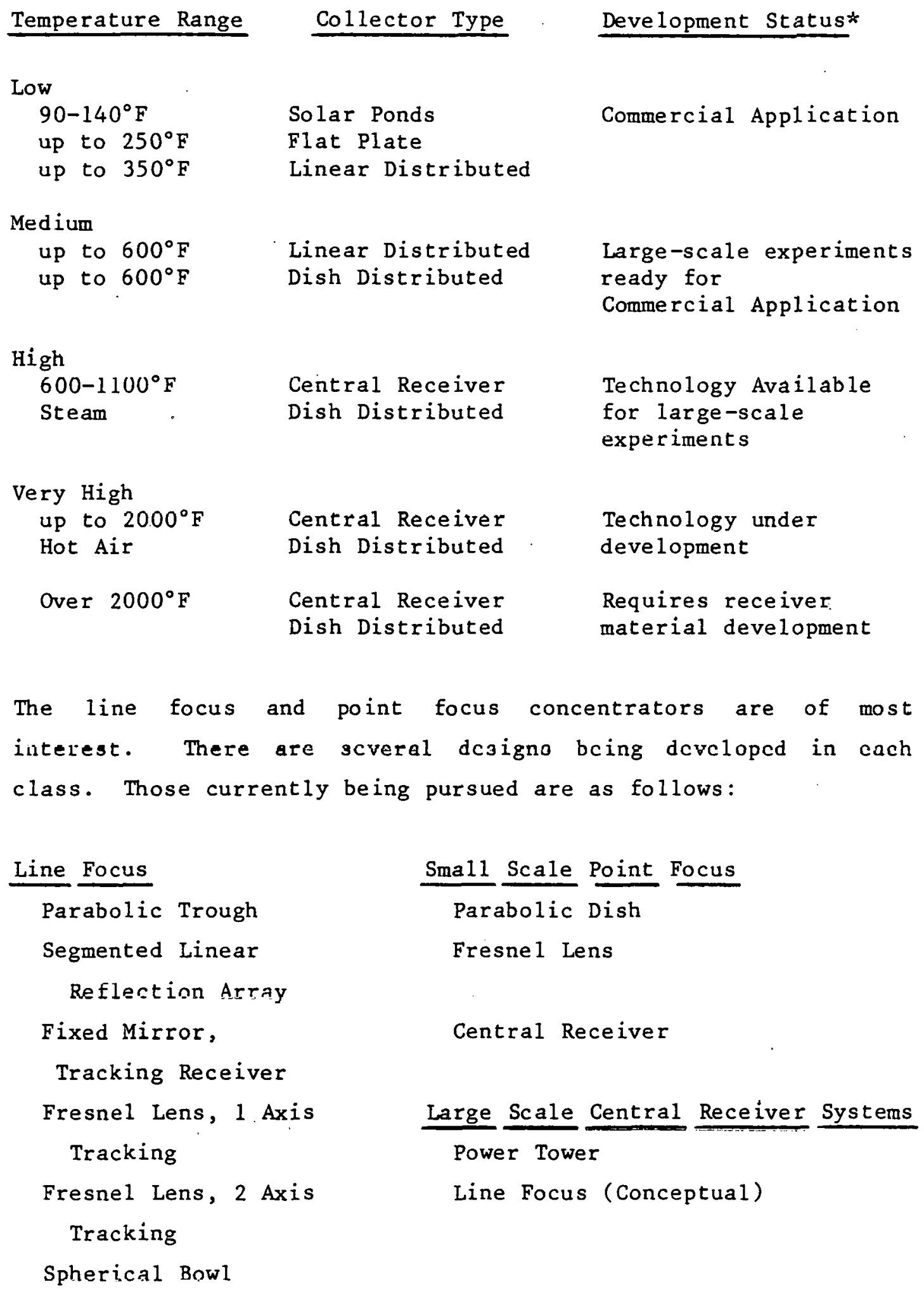

*Data from Aerospace, Ref. 4 
The best performing class or design is not clear at this time, and several collector types will probably be commercialized. Figure II-2 presents typical collector efficiencies for line and point focus. These data are normally the peak efficiency (i.e., solar noon with clear day insolation); all radiation is direct normal. On an annual basis, much of the insolation is diffuse and is interrupted by clouds. Thus, the annual efficiency is much lower. For a parabolic trough the efficiency is reduced from a peak of $55 \%$ at $250^{\circ} \mathrm{C}\left(\approx 500^{\circ} \mathrm{F}\right)$ to about $40 \%$ annual. Similar reduction also occurs for point focusing devices.

Appendix A presents typical annual collected energy data for two types of collectors. Parabolic troughs and dishes operating on several conditions within the continental United States are considered. A cost calculation for solar versus oil is included. The conditions are ( 1 ) oil costing $\$ 5 / M B t u$ in the first year of operation, (2) $5 \%$ inflation, (3) plus $5 \%$ fuel escalation (total price increase of $10 \%$ per year), (4) a 20-year lifetime, (5) $10 \%$ investment tax credit (no special solar tax incentive), (6) a fuel saver model of operation, and (7) regional oil price variation as in 1977. Data for cost competitiveness are presented as a function of the region. If the initial turn-key installed cost is $\$ 30 / f t^{2}$ for parabolic troughs, then solar thermal process heat would cost up to five times as much as an oil system. For a parabolic dish at $\$ 30 / \mathrm{ft}^{2}$, the cost of solar is 1.5 to 3.0 times the cost of oil. However, if the price of the collectors could be lowered to $\$ 15 / \mathrm{ft}^{2}$ or less, then solar can become cost-competitive with oil without a special solar tax credit.

Recognizing that near-term cost projections for some solar systems are on the order of $\$ 30 / \mathrm{ft}^{2}$ installed, the cost of solar is clearly a major barrier. DOE's cost goals are $\$ 6 / \mathrm{ft}^{2}$ for point focus and $\$ 7 / \mathrm{ft}^{2}$ for line focus [8]. At the cost goals solar process heat will be competitive with fossil fuels, but the time 


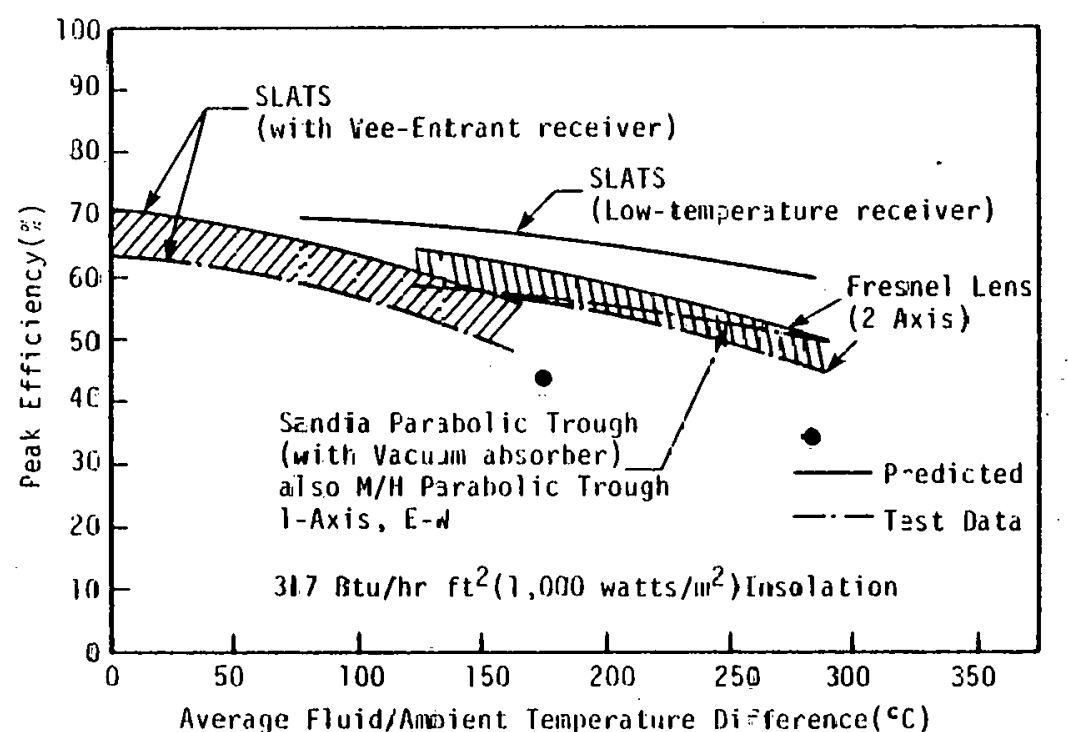

Coll ector Efficiencies*

- Parabolic Trougl at Albuquerque, N.M. Annual Basis, from Sandia, March 1978
Peak Efficiency $(\eta)$

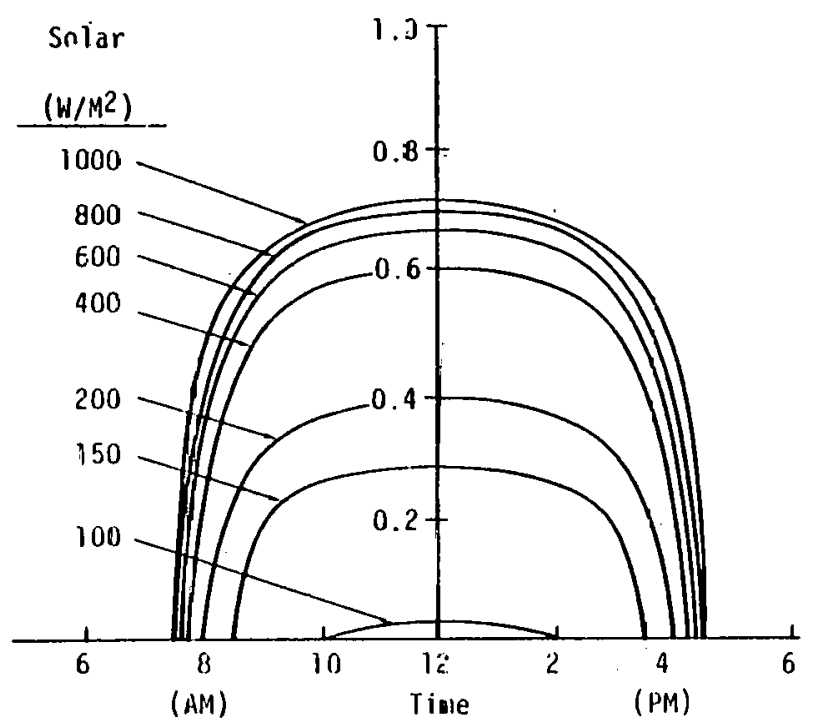

Central Receiver System Performance(Winter Solstice)*

*From McDonue11 Douglas, "Iridustrial Applications of Total Energy", HDC 66772, April 1972.

Figure II-2. Current Efficiencies of Solar Collectors 
frame will be after 1986. Special tax credits could be given to solar; however, the considerations of tax incentives was beyond the scope of this study. 
III. A PRELIMINARY EVALUATION OF

THE POTENTIAL FOR SOLAR-THERMAL PROCESS HEAT

IN PETROLEUM REFINING

A.

OBJECTIVE

An analysis was conducted of petroleum refining. The potential market size and some problems of utilizing solar thermal heat were identified. The approach was to identify (1) how process heat was utilized, (2) how much land area would be needed, and (3) potential problems in the integration of solar-themal in the system. Finally, one technology was identified for detailed study and was described.

B. REFINERY ENERGY REQUIREMENTS

Refineries are very large users of energy. About $10 \%$ to $12 \%$ of the energy value of the crude oil is consumed in the refining process [1]. Table III-1 presents the types and quantity of fuels used in refineries. Natural gas and refining gas are the two largest fuel sources. Clearly, if solar thermal were used, natural gas and other high value fuels could be made available for other applications. Further, the refinery would save the cost of a rapidly escalating fuel (methane).

Many refineries are located in areas of high insolation. Eight states (Arizona, California, Colorado, Florida, Nevada, New Mexico, Texas, and Utah) have $41.9 \%$ of the U. S. refining capacity. According to Battelle [1], there are only 99 refineries in these states. The refineries in those eight states consume about $2 \%$ of all U. S. energy. Clearly, this potential market for solar process heat is very large. 
TABLE III-1

REFINERY FUEL AND ENERGY SOURCES (1969'

Fuel

Fuel oil, 1,000 bbl

Acid sluage, $1,300 \mathrm{bbl}$

Coal, 1, 000 tons

Natural gas, Mcf

Refining gas, Mcf

Petroleun coke, 1,000 tons

Purchased electricity, MkWh

LPG, 1,0ज̃0 bbl

Purchased steam, Mib

Crude oil run to sills, Mbbl
Total enargy equivalent, $10^{12}$ Btu

Quantity/year

$10^{12} \mathrm{Btu} /$ year

$\begin{array}{rr}43,323 & 263 \\ 95 & 0 \\ 570 & 14 \\ 997,886 & 998 \\ 984,561 & 1,000 \\ 10,625 & 320 \\ 17,927 & 61 \\ 6,620 & 25 \\ 24,396 & 27 \\ -- & 2,718 \\ 3,880 & -- \\ 703,000 & -- \\ 12 \% \text { of energy content of the oil }\end{array}$

American Petroleum Institute, "Petroleum Facts and Figures," 1971 Edition, Washington. 
A Nominal Refinery Size

Table III-2 presents data on the size and number of U. S. refineries. Sizes range from as small as $5,000 \mathrm{~B} / \mathrm{cd}$ to over $300,000 \mathrm{~B} / \mathrm{Cd}$. Rather than work with every single size of refinery at this point in time, a nominal refinery size will be defined. For this study, a nominal refinery is defined as the size at which half of U. S. oil is refined in plants of larger size and half in refineries of smaller size. This definition is not the same as the average or median. The difference is illustrated below:

\footnotetext{
Refinery Size

Capacity

Median capacity for 259 refineries = $28,500 \mathrm{~B} / \mathrm{Cd}$

(128 smaller, 128 larger)

Average Capacity

$=\quad 57,318 \mathrm{~B} / \mathrm{cd}$

(total capacity divided

by number of units)

Nominal Capacity

$=\quad 120,000 \mathrm{~B} / \mathrm{cd}$

(represents about half of U.S. refining capacity

in refineries of larger size and half

in refineries of smaller size)
}

The nominal size is assumed to be more representative of future refineries because the smaller ones are less efficient, older, and subject to replaceüent.

Refinery Process Heat Utilization

This section discusses the utilization of process heat in a refinery. Figure III-1 presents the various processing steps in the refining operation. Heat and work are used/produced in all of the steps. Conservation principles are currently employed in a refinery; typically the hot product stream for one step is used to either preheat the incoming stream or to supply heat for a lower 
TABLE III-2

U. S. REFINERY SIZE DISTRIBUTION

(AS OF JANUARY 1, 1975)

\begin{tabular}{ccccc}
$\begin{array}{c}\text { Capacity Rapge, } \\
10 \mathrm{~B} / \mathrm{CD} ! \mathrm{a})\end{array}$ & $\begin{array}{c}\text { Number of } \\
\text { Refineries }\end{array}$ & $\begin{array}{c}\text { Total Capacity, } \\
\mathrm{B} / \mathrm{CD}(\mathrm{g})\end{array}$ & $\begin{array}{c}\text { Percent of } \\
\text { Capacity }\end{array}$ & $\begin{array}{c}\text { Average Capacity, } \\
\mathrm{B} / \mathrm{CD} \text { (a) }\end{array}$ \\
\hline$<5$ & 49 & 146,592 & 0.99 & 2,992 \\
$5-10$ & 31 & 230,688 & 1.55 & 7,442 \\
$10-15$ & 19 & 234,780 & 1.58 & 12,357 \\
$15-25$ & 25 & 517,520 & 3.49 & 20,701 \\
$25-50$ & 50 & $1,910,592$ & 12.87 & 38,712 \\
$50-75$ & 21 & $1,369,385$ & 8.82 & 62,352 \\
$75-100$ & 21 & $1,878,950$ & 12.66 & 89,474 \\
$100-200$ & 28 & $4,0 C 2,900$ & 26.96 & 142,961 \\
$>200$ & 15 & $4,614,000$ & 31.08 & 307,600 \\
TOTAL & 259 & $14,845,407$ & 100.00 & 57,318 \\
\hline
\end{tabular}

(a) B/CD - barrels per calendar day. 1 barrel - 42 gallons - 158.97 liters.

(b) Typically refineries operate 24 rours every day with a capacity factor of 0.94 to 0.95 .

$B / C d=0.94 \mathrm{~B} /($ stream day $)$

Source: Dil and Gas Journal, April 7, 1975, pp. 98-118. 


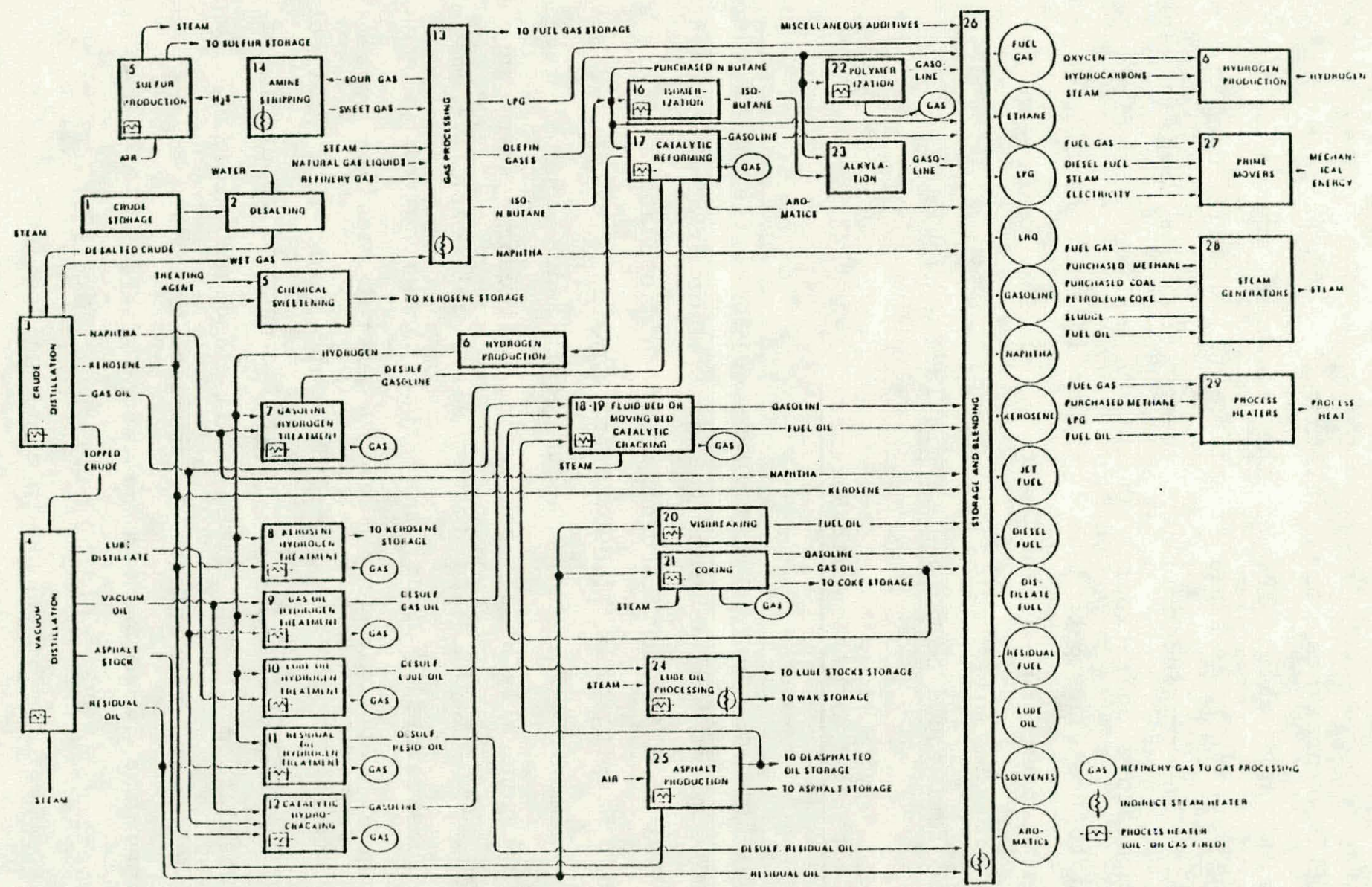

Source: Batelle, Ref. I

Figure III-1. Process Flow Diagram of Petroleum Refining Industry 
temperature process. Consequently, there is excess steam generating capacity (at $375^{\circ}$ and $290^{\circ} \mathrm{F}$ ). The excess is vented or sold if another industry is located nearby.

Table III-3 presents the utilization of process heat in refining. Only about $12 \%$ of the consumed energy is used in producing steam. A small fraction $(\approx 4 \%)$ is used to make hydrogen. The remainder of the energy ( $84 \%)$ is used in various high temperature operations. Currently, oil- or gas-fired units are used to heat the petroleum. Either indirect heating (via air or other medium) or direct heating of the petroleum in the receiver of the solar collector could be used. Alternatively, synthetic fuel could be burned to displace a higher value fuel.

Solar Field Size for a Nominal Refinery

A $120,000 \mathrm{~B} / \mathrm{Cd}$ refinery will require a very large solar thermal field. The plant will consume the equivalent of 12,000 to 14,000 $\mathrm{B} / \mathrm{Cd}$ or 7.2 to $8.6(10)^{10} \mathrm{Btu} / \mathrm{day}$. If the insolation at the site is $580,000 \mathrm{Btu} / \mathrm{ft}^{2}$ year $\left(1,600 \mathrm{Btu} / \mathrm{ft}^{2}\right.$ day $)$ an area of 1.8 square miles is needed. For large heat requirements central receiver systems are generally best; that solar collector system can cover only about $35 \%$ of the land (other solar collector systems have similar constraints). Thus, the total land required is about 5 square miles. Approximatcly 9 or 10 central receiver systems of $100 \mathrm{MW}_{e}$ rating would be needed even with $100 \%$ cullectiun efficiency. With a real collection efficiency of about $50 \%$ of the direct insolation at the site, a five square mile area would supply half of a refinery's process heat. Figure III-2 illustrates how large such a collector field is. A heliostat field covering an area of 2.23 miles by 2.23 miles will be needed to supply $50 \%$ of the heat used in a nominal refinery. 
TABLE II I -3

REFINERY USAGE OF PROCESS HEAT

Form of Process Heat

Steam

$450^{\circ} \mathrm{F}$ at $450 \mathrm{psig}$ (co and steam boiler)

Hydrogen Production $\left(>1000^{\circ} \mathrm{F}\right)$

Direct Heating of Product

Crude distillation at $650^{\circ} \mathrm{F}$

Vacuum distillation at $780^{\circ} \mathrm{F}$

Various hydrogen treatments at $800^{\circ} \mathrm{F}$

Catalytic hydro-cracking at $800^{\circ} \mathrm{F}$

Various catalytic cracking and reforming $\left(900^{\circ}-1200^{\circ} \mathrm{F}\right)$

Coking $\left(1050^{\circ} \mathrm{F}\right)$

Asphalt processing $\left(500^{\circ} \mathrm{F}\right)$

TOTAL
Total 1974 Annual Use of $\left(10^{12}\right.$ Btu)

$\begin{array}{lr}380 & (12 \%) \\ 128(2) & (4 \%) \\ 2588) & (84 \%) \\ 380 & \\ 59 & \\ 126 & \\ 624 & \\ 961 & \\ 381 & \\ 53 & \\ 4 & \\ 3090 & \end{array}$

(1) From Battelle, Volume 2, Table 5, pages 442/443, and Table 1, page 6 (Ref. 1)

(2) Estimated by Copeland $1-16-78$ based on approximate $\mathrm{H}_{2}$ balance of uses and sources within a refinery. 


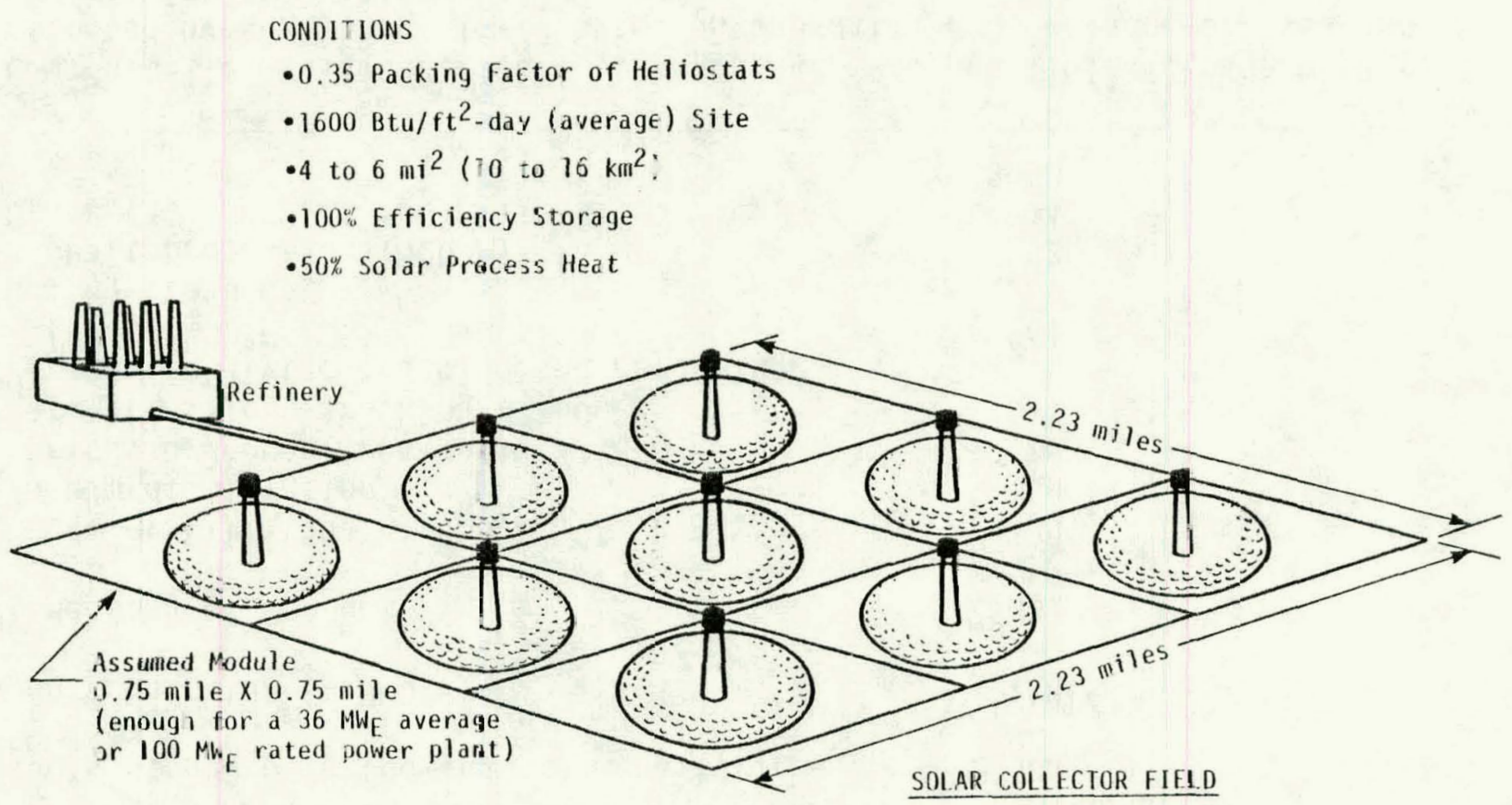

Figure III-2. Approx -mate Size of a Solar-Thermal Field for a Nominal Refinery $(120,000 \mathrm{~B} / \mathrm{cd})$ 
Two significant problems are anticipated due to the large size of the solar plant. One problem is the difficulty of transporting thermal energy over distances which may amount to several miles of piping. The piping will be costly, and the thermal losses from $1000^{\circ} \mathrm{F}$ to $1600^{\circ} \mathrm{F}$ lines will be large. The second problem is the availability of land to site the heliostat field. For large industrial users of energy, the second problem may be more limiting than the first and is discussed in more detail in the next section.

Siting Limitations for Petroleum Refineries

A solar thermal collector may be located near the end use or at a remote site. The first choice is always locating the solar equipment near the use to minimize the costs and losses from piping. When the solar field is located at a distance, a type of chemical heat pipe may be needed. The chemical heat pipes transport high energy density fluids at ambient temperatures. The chemical heat pipes require (1) both supply and return piping, (2) receiver to convert solar heat into chemical energy, and (3) reactors to convert chemical energy back into thermal energy. Because of the high cost and inherent efficiency losses, a direct utilization of the heat will always be cheaper unless the distances are great.

Figure III-3 illustrates the probable siting problem for large industrial plants. The map is of the Houston and Galveston, Texas area. The Humble Baytown Refinery (of Exxon) location is shown. The plant is located near the Houston Ship Channel in a residential and industrial area; little if any undeveloped land is available in the immediate area. Although there may be unused land at the Humble Baytown Refinery, this land may be held in reserve for future plant expansion, modification, petrochemicals production, etc. Assuming there was insufficient on-site land 


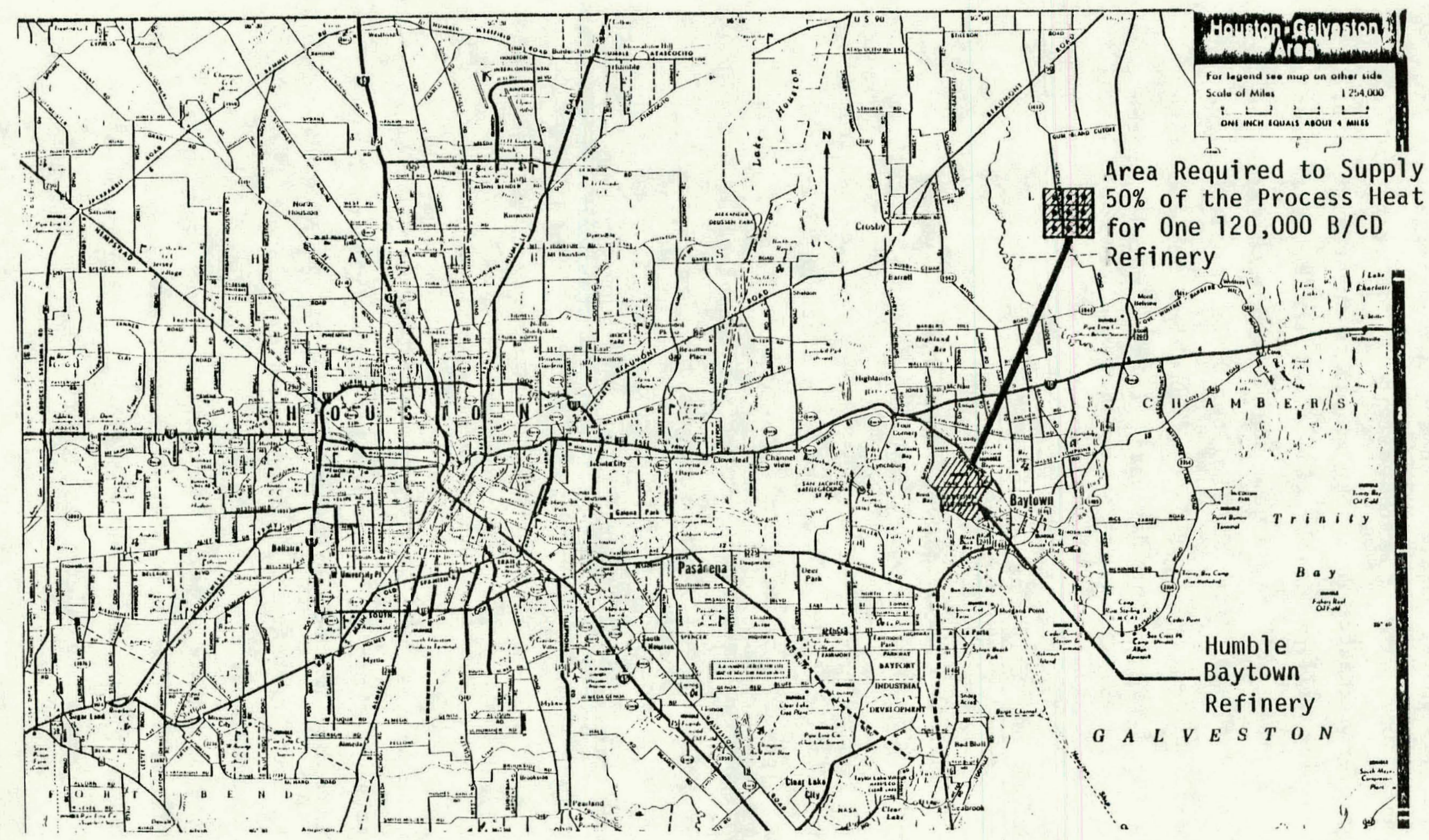

Figure III-3. Siting of a Solar Field for the Humble Baytown Refinery 
available, the collector field was arbitrarily located in an undeveloped area. The distance between the field and the refinery is about $10 \mathrm{miles}(16.1 \mathrm{~km})$. However, to obtain the land, it is highly unlikely that a large block of land could be bought in a single site. Furthermore, to buy the land at near minimum cost, even greater distances (on the order of 30 miles) can be expected. The siting problem will be further complicated by other industrial users in large metroplexes. For example, in the Houston area there are at least eight oil refineries.* Due to the competition for land for solar collectors, even larger distances may be. necessary for large scale solar collectors. Even refineries located in low population areas can expect siting problems. These problems will arise from refusal of current owners to sell, high cost of adjacent land, or unsuitable land (e.g., poor soil strength, north side of hill, etc.).

The siting problem for the Houston refineries is not an isolated case. Table III-4 presents data for Shell oil Refineries located west of the Mississippi. The data indicate what fraction of the steam can be supplied by solar energy from the available land currently unused at each Shell refinery. The range is from $8 \%$ to $525 \%$ at a given refinery. However, the one site at Houston represents $81 \%$ of the total steam utilization (and refining capacity). Thus, although there may be available land at all western sites, the net impact is that solar can supply less than $13 \%$ of the steam used in Shell refineries, greatly reducing the potential market for solar-process heat. Because of the tendency for large industries to locate in urban areas, the land availability limit is expected to apply to all energy intensive industries,

* Based on data from Aerospace, Ref. 4. 
TABLE II I-4

SHELL OIL REFINERIES*

(WEST OF THE MISSISSIPPI)

\begin{tabular}{|c|c|c|c|c|c|}
\hline Site & $\begin{array}{c}\text { Steam Generator } \\
\text { No. Units--MBtu/hr }\end{array}$ & $\begin{array}{l}\text { Heat Medium } \\
\text { No. Units--MBtu/hr }\end{array}$ & $\begin{array}{c}\text { Approx. } \\
\text { Non-Process } \\
\text { Acreage } \\
\end{array}$ & $\begin{array}{l}\text { Average Daily } \\
\text { Insolation } \\
\mathrm{kWh} / \mathrm{m}^{2} \\
\end{array}$ & $\begin{array}{l}\text { Potential Solar } \\
\text { Steam Generation } \\
\% \text { of Total Steam }\end{array}$ \\
\hline Houston, TX & $\begin{array}{l}4-125 \\
5-330 \\
1-480 \\
3-360 \\
1-730 \\
4-620\end{array}$ & $\begin{array}{l}1-150 \\
1-220\end{array}$ & 320 & $6-7$ & $8.1 \%$ \\
\hline Los Angeles, CA & $\begin{array}{l}1-220 \\
2-350\end{array}$ & $1-120$ & 80 & $6-7$ & $15.2 \%$ \\
\hline Odessa; TX & $1-200$ & & 600 & $7-8$ & $525.0 \%$ \\
\hline Ciniza, NM & $1-200$ & & 150 & $7-8$ & $150 \%$ \\
\hline Geismar, LA & $2-290$ & $1-150$ & 200 & $<6$ & $-\cdots$ \\
\hline
\end{tabular}

*Data from Aerospace, Ref. 4 
All of the above factors illustrate the siting problem. Clearly, if solar is to make a significant penetration in high temperature process heat, the land availability limit must be overcome. A good long distance energy transfer technology would provide the required means; candidate technologies include thermal. transport (e.g., pressurized water), chemical heat pipes (e.g., $\mathrm{SO}_{3} \rightarrow \mathrm{SO}_{2}+$ $\left.1 / 2 \mathrm{O}_{2}\right)$, and synthetic fuels. The next section examines one transport technology in more detail.

C. SOLAR THERMAL HYDROGEN PRODUCTION

This study seeks to examine a single technology to identify development needs. Obviously, all candidate technologies for energy transfer should be investigated. For the limited resources of this study, only one can be investigated and then only briefly. The candidates are:

1. steam

2. synthetic fuel

3. direct heat

4. chemical heat pipes

5. Sensible heat (air, liquid, metals, molten salts, etc.)

All of these can be expected to be utilized in future industrial applications. For this study the synthetic fuel route was chosen. This route is applicable to any industry and could have a significant fossil fuel reduction in all. Hydrogen was chosen because it is currently used in refineries and can be used as a general fuel. Hydrogen is a medium Btu gas ( $350 \mathrm{Btu} / \mathrm{ft}^{3}$ ); carbon monoxide is also a medium Btu gas. Many synthetic fuels can be produced at lowest costs with $\mathrm{CO}$ in the product; but because of the toxicity of $\mathrm{CO}$, it was assumed unacceptable for pipelines in urban areas. Only $\mathrm{H}_{2}$ and familiar hydrocarbons were considered acceptable from a safety point of view. 


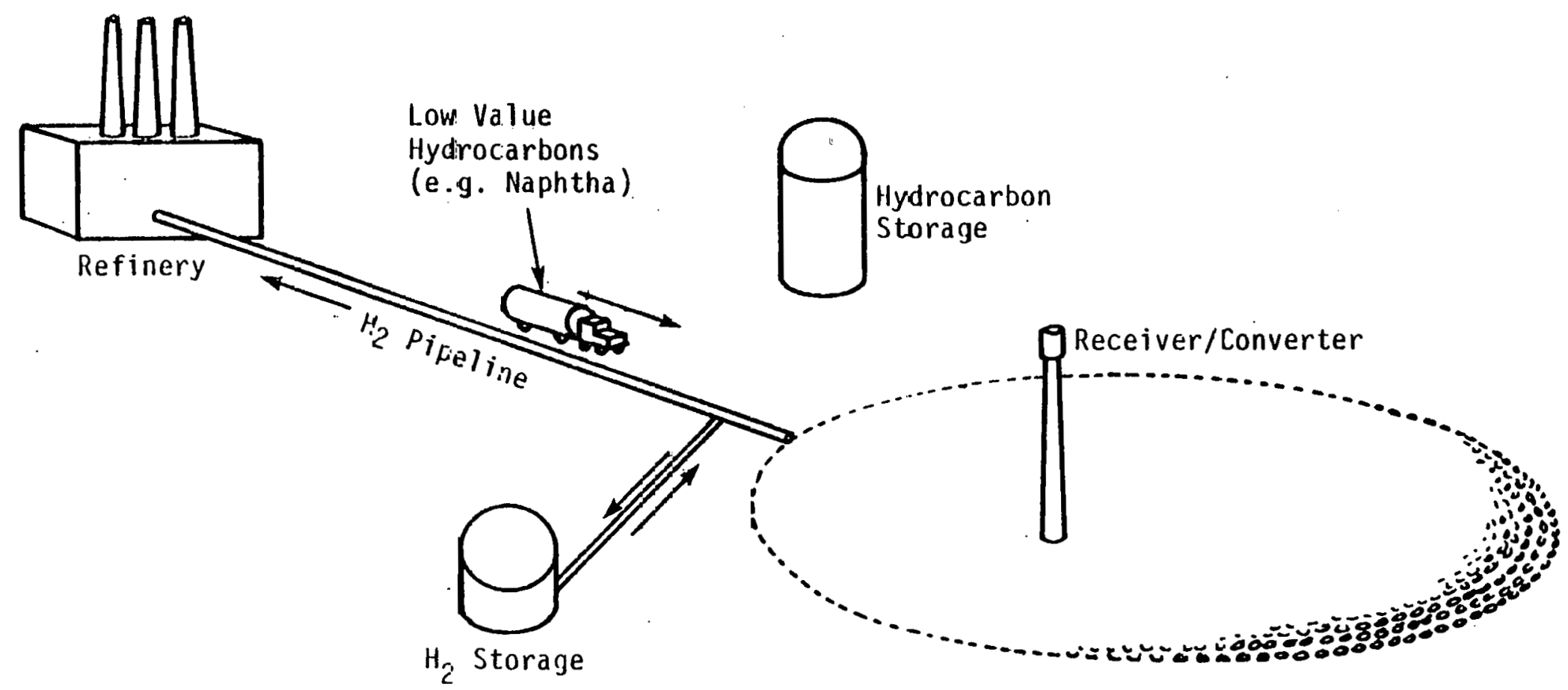

Ficure III-4. $\mathrm{H}_{2}$ Production Approach 
Hydrogen Production Approach

Figure III-4 presents the selected approach for the production of hydrogen. In this concept low value hydrocarbons (e.g., naphtha) are converted to hydrogen with the addition of solar heat. The heating value of the hydrocarbon is increased by about $25 \%$ due to the addition of the solar energy. The refinery and solar field are separated by a long distance, something like 10 to 100 miles. The hydrocarbons are transferred by truck (or pipeline) to the solar field. At the field, the hydrogen is produced and stored. A pipeline transfers the gas to the refinery. In the refinery the $\mathrm{H}_{2}$ is burned in existing gas-fired heaters. Because of the similarity to methane, only minor modifications to heaters would be necessary to burn $\mathrm{H}_{2}$.

Water-Gas Reaction

The hydrogen is produced by the water-gas reaction with the addi= tion of heat. The water-gas reaction converts a carbon containing fuel material in the presence of steam to carbon monoxide and hydrogen. The reaction is as follows:

$$
\mathrm{CH}_{\mathrm{x}}+\mathrm{H}_{2} \mathrm{O}+\text { heat } \rightarrow \mathrm{CO}+\left(1+\mathrm{x} /{ }_{2}\right) \mathrm{H}_{2}
$$

The reaction occurs at $1000^{\circ} \mathrm{F}$ to $1600^{\circ} \mathrm{F}$. The products are primarily $\mathrm{CO}$ and $\mathrm{H}_{2}$, but small amounts of $\mathrm{CO}_{2}$ and light hydrocarbons are also formed. This reaction (but with a fossil fuel heat source) is currently. used to generate hydrogen for refineries, ammonia, and other industrial uses.

Table III-5 presents the increase in heating value for several hydrocarbon feed stocks. Depending upon the hydrocarbon, a $23 \%$ to $44 \%$ increase results from the addition of solar heat. The reaction will occur as indicated with any hydrocarbon including 
TABLE III-5

THERMOCHEMISTRY OF THE WATER-GAS REACTION

\begin{tabular}{|c|c|c|c|c|c|c|}
\hline & llydro carbon & $\begin{array}{l}\text { Molecular } \\
\text { Weight }\end{array}$ & Reaction & $\begin{array}{l}\text { Carbon }\left(8 t u / 1 b_{\text {m }} \text { (1) }\right. \\
\left.\text { of } C_{x} H_{y}\right)\end{array}$ & $\begin{array}{c}\left(B t u / d b_{m}\right. \\
\left.C_{x} H_{y}\right)\end{array}$ & $\begin{array}{l}\text { Percent } \\
\text { Increase }\end{array}$ \\
\hline & Carbon (s) & 12.01 & $\mathrm{C}+\mathrm{H}_{2} \mathrm{O}+\mathrm{CO}+\mathrm{H}_{2}$ & $\begin{array}{l}14,107 \\
(14,107)\end{array}$ & $\begin{array}{c}20,326 \\
(18,802)\end{array}$ & $\begin{array}{l}44.44 \\
(33.34)\end{array}$ \\
\hline 1 & Methane $(g)$ & 16.01 & $\mathrm{CH}_{4}+\mathrm{H}_{2} \mathrm{O}+\mathrm{CO}+3 \mathrm{H}_{2}$ & $\begin{array}{l}23,861 \\
(? 1,502)\end{array}$ & $\begin{array}{l}30,590 \\
(27,055)\end{array}$ & $\begin{array}{l}28.2 \% \\
(25.8 \%)\end{array}$ \\
\hline & Ethane $(g)$ & 30.07 & $\mathrm{C}_{2} \mathrm{H}_{6}+2 \mathrm{H}_{2} \mathrm{O}+2 \mathrm{CO}+5 \mathrm{H}_{2}$ & $\begin{array}{l}22,304 \\
(\geq 0,416)\end{array}$ & $\begin{array}{l}28,545 \\
(25,402)\end{array}$ & $\begin{array}{l}28.0 \% \\
(24.4 \%)\end{array}$ \\
\hline & Benzene (1) & $? 8.11$ & $\mathrm{C}_{6} \mathrm{H}_{6}+6 \mathrm{H}_{2} \mathrm{O}+6 \mathrm{CO}+9 \mathrm{H}_{2}$ & $\begin{array}{l}17,985 \\
(17,259)\end{array}$ & $\begin{array}{c}23,521 \\
(21,343)\end{array}$ & $\begin{array}{c}30.8 \% \\
(23.7 \%)\end{array}$ \\
\hline & Octane (1) & 1.14 .13 & $\mathrm{C}_{8} \mathrm{H}_{18}+8 \mathrm{H}_{2} \mathrm{O} \rightarrow 17 \mathrm{H}_{2}+8 \mathrm{CO}$ & $\begin{array}{l}20,591 \\
(19,256)\end{array}$ & $\begin{array}{l}\geq 6,827 \\
(24,015)\end{array}$ & $\begin{array}{l}30.3 \% \\
(24.7 \%)\end{array}$ \\
\hline & Butylbenzene & 134.21 & $\mathrm{C}_{10} \mathrm{H}_{14}+1 \mathrm{OH}_{2} \mathrm{O} \rightarrow 10 \mathrm{ZO}+1 \mathrm{ZH}_{2}$ & $\begin{array}{l}18,802 \\
(17,823)\end{array}$ & $\begin{array}{l}\geq 4,648 \\
(\geq 2,639)\end{array}$ & $\begin{array}{l}32.0 \% \\
(27.0 \%)\end{array}$ \\
\hline & Delene $(g)$ & 140.26 & $\mathrm{C}_{10} \mathrm{H}_{2 \mathrm{O}}+1 \mathrm{OH}_{2} \mathrm{O}+1 \mathrm{Oi} \mathrm{OO}+2 \mathrm{GH}_{2}$ & $\begin{array}{l}20,444 \\
(19,094)\end{array}$ & $\begin{array}{l}? 6,214 \\
(? 3,520)\end{array}$ & $\begin{array}{c}28.2 \% \\
(23.2 \%)\end{array}$ \\
\hline
\end{tabular}

value of Hydro-

Heating Value of

Products per weight

of indrocarbon

Notes: (1) Higher heating value, lower heating value in parenthesis ( )

(2) Based upon original weight of hydracarbon 
methane, naphtha, coal, biomass, etc. The co which is produced maybe eliminated by the water-gas shift reaction; that reaction is as follows:

$$
\mathrm{CO}_{(\mathrm{g})}+\mathrm{H}_{2} \mathrm{O}(\mathrm{g}) \rightarrow \mathrm{CO}_{2(\mathrm{~g})}+\mathrm{H}_{2(\mathrm{~g})}+[631 \mathrm{Btu} / 1 \mathrm{~b} \text { of } \mathrm{CO}]
$$

or if the water is initially in a liquid state:

$$
\mathrm{CO}_{(\mathrm{g})}+\mathrm{H}_{2} \mathrm{O}(\mathrm{I}) \rightarrow \mathrm{CO}_{2(\mathrm{~g})}+\mathrm{H}_{2(\mathrm{~g})}-[44 \mathrm{Btu} / 1 \mathrm{~b} \text { of } \mathrm{CO}]
$$

The difference in the above equations is whether the water is supplied as a gas ( $g$ ) or liquid ( 1 ). Nominally, the reaction is slightly exothermic, and occurs at $700^{\circ} \mathrm{F}$ in the presence of a catalyst. Following the reaction, the $\mathrm{CO}_{2}$ is removed and vented leaving a stream of hydrogen. All equipment required to conduct the water-gas shift reaction is state-of-the-art; the process has been in commercial use in petroleum refineries for many years.

The hydrogen approach to energy transfer has many advantages for industrial users, particularly petroleum refineries. Because refineries are current users, they make a logical first choice for application. If the concept is successful and if the safety hazards are acceptable, a mixture of $\mathrm{CO}$ and $\mathrm{H}_{2}$ may be used in other industries at a lower cost than $\mathrm{H}_{2}$.

The major barrier to the implementation of a synthetic fuel technology is cost. Currently, solar-thermal heat is very expensive even when compared to imported oil. At the DOE goals, solarthermal heat costs can become lower than alternative oil or gas. Thus, although much work remains to verify these data, solar thermal process heat and/or synthetic fuels are within the realm of economic possibilities. 
IV. DEVELOPMENT NEEDS

The utilization of solar thermal technology for high temperature process heat will require new developments. This section presents the needs identified in this study. The first section discusses the technical development requirements, and the second section discusses economic issues.

\section{A. TECHNICAL DEVELOPMENT NEEDS}

Three areas of technical development for high temperature process heat have been identified: (1) solar collectors, (2) energy transfer, and (3) system integration. Each is discussed below.

Solar Collectors

Solar Thermal technologies are being developed for electric power and low temperature process heat. Those programs will produce hardware suitable for generating process heat at high temperatures. No new solar collector system development programs are needed specifically for process heat. Some development of receivers may be desired. Direct heating of petroleum in refineries or raw materials in other industries may be beneficial since it would avoid thermal losses. In addition, new processes or new products utilizing the unique nature of concentrated sunlight may reduce the energy costs even more.

Energy Transfer

The siting problem which was identified for petroleum refining is expected to exist in all energy intensive industries. The land, roof, parking lot, etc. areas immediately adjacent can be expected to be limited relative to the quantity of heat utilized. Thus, the potential market for solar process heat may be very limited. 
An energy transfer system would eliminate this restriction. Candidate technologies are as follows:
(1) steam
(2) sensible heat fluids
(3) chemical heat pipes
(4) synthetic fuel

One candidate technology was investigated in this study. The cuncept was a medium Btu gas (hydrogen) made from solar thermal heat and low value hydrocarbons. At the use site a $25 \%$ increase in heating value of the initial fuel was estimated (due to the addition of the solar thermal heat). No attempt was made to identify the optimum energy transfer system, and no one best technology can be expected to emerge. Research and development in all energy transfer technologies are recommended.

\section{System Integration}

The integration of a solar thermal process heat source with an industry is a necessary part of the implementation. System application ctudioe are recommended; thoso analyses will identify precisely how a solar thermal heat source will interface with the processes. Key areas to be considered are (1) siting and geographic area, (2) losses, (3) capability of using direct heat, and (4) retrofits and new construction. Each major industry must be evaluated in detail. These industries are as follows:

\footnotetext{
- petroleum refining

- steel and iron

- cement

- glass

- ceramics

- chemicals
} 
The geographic distribution, temperatures, processes, new plant additions, etc. are different in each industry; and the obtainable market for solar thermal will be different. Based upon the results of early applications analysis, detail requirments can then be identified.

\section{B. WHAT IS ECONOMIC?}

The market penetration by solar thermal technology will be most strongly influenced by the cost of both solar and alternative fuels. Currently the cost of solar thermal heat is high. The ongoing DOE development programs are expected to greatly lower the collector cost. The cost of energy from the solar thermal plant is predominantly capital: the cost of delivered solar thermal energy is thus dependent upon the method of amortizing the capital. According to Aerospace (Ref. 4), industries typically want 3 to 8 years payback on capital investments. The payback is not only a function of the time, but also the site, the cost of the alternative fuels, and the interest rate. For a typical interest rate and collector efficiency this dependence is illustrated below: 
BREAK-EVEN INSTALLED COSTS*

Average Daily

Insolation Fuel Maximum Cost for Maximum Cost for $\mathrm{kWh} / \mathrm{m}^{2} \quad \$ / \mathrm{MBtu} \quad 5 \mathrm{Yr}$. Payback $\$ / \mathrm{ft}^{2} \quad 8 \mathrm{Yr}$. Payback $\$ / \mathrm{ft}^{2}$

$\begin{array}{rrrr}8 & 2.50 & 5.10 & 10.22 \\ 8 & 4.00 & 8.16 & 16.35 \\ 7 & 2.50 & 4.46 & 8.94 \\ 7 & 4.00 & 7.14 & 14.30 \\ 6 & 2.50 & 3.83 & 7.67 \\ 6 & 4.00 & 6.12 & 12.26\end{array}$

For these data the break-even costs vary from $\$ 3.83 / \mathrm{ft}^{2}$ to $\$ 16.35$ dependent upon factors not associated with the solar equipment. The variance would be even greater if a full range of intarest rates, payback period, life-cycle costing methods, etc. were considered. These factors can only be properly assessed by an in-depth study. Case studies for several sites in each of the major industries are recommended.

Solar thermal technology has benefits beyond cost savings to the user. These factors are (1) freedom from curtailment, embargos, strikes; (2) long-term assured source of supply; and (3) insulation from future price increases. Clearly, these items are of value to the user; however, a reliahle methodology for determining that value in quantitative terms is not known.

* From Ref. 4. Installed costs in this example included the collectors, installation, site preparation, interest during construction, etc.; i.e., all costs associated with the solar collector system. 


\section{REFERENCES}

1. Anon "Survey of the Applications of Solar-Thermal Energy Systems to Industrial Process Heat," Battelle Columbus Laboratories, Columbus, Ohio; Honeywell Incorporated, Minneapolis, Minn., Battelle Pacific Northwest Laboratories, Richland, Washington; Contract No. W-7405-ENG-92, Report No. W-7405-ENG-92, Report No. TID-2734811, 3 Volumes, January 1977.

2. Anon, "Analysis of the Economic Potential of Solar Thermal Energy to Provide Industrial Process Heat," 3 Volumes, Report No. COO/2829-76/1, Contract No. EY-76-C-02-2829.008, InterTechnology Corporation, Warrenton, Virginia, February 1977.

3. Anon, "Industrial Applications of Solar Total Energy," 5 Volumes, Report No. SAN-1132-2 (also MDAC Report No. NIDC G6722) ERDA Contract EY-C-76-03-1132, April 1977.

4. Anon, "High-Temperature Industrial Process Heat, Technology Assessment and Introduction Rationale," The Aerospace Corp., Report No. ATR-78(7691-03)-2, DOE Contract No. E(04-3)-1101, March 3, 1978.

5. Solar Energy for Agriculture and Industrial Process Heat-Program Summary, June 1977, ERDA 77-72, Division of Solar Energy, ERDA.

6. Copeland, R. J., "High Temperature Technology for Process Heat and Other Applications, A Program Strategy for Dispersed Solar-Thermal Power Systems," SERI Document No. 3500-RJC-123, April 11, 1978, revised May 8, 1978. 
7. Stanford Research Institute, "Patterns of Energy Consumption in the United States," Office of Science and Technology, Executive Office of the President, Washington, D.C., January 1977.

8. Braun, G., "Review of Baseline Plan" presentation at Thermal Power Systems Planning Seminar, February 13-14, 1978 at SERI, Golden, Colorado. 


\section{APPENDIX*}

Availability and Performance Contour Maps for Tracking Collector Systems in the United States.

* These data were taken from Lameiro, Gerard F. and Brown, Kenneth C., "Industrial Process End Use Matching, Technical Planning Report," SERI-27, April 1978. 
There appears to be a need for some way of quickly referencing information on the performance potential of tracking solar collectors in various regions of the United States. A map which shows isopleths of annual deliverable heat for various types of collectors is the most convenient form of presentation. Maps have already been constructed for flat-plate collectors used in SHAC applications (InterTechnology Corporation); but until now, no such maps have been available for tracking collectors of the type which will most likely be used in industrial process heat systems.

Publication of a report by É. Boes, et $a 1 .$, at Sandia entitled "Availability of Direct, Total, and Diffuse Solar Radiation to Fixed and Tracking Collectors in the U.S.A." [A1] allows initial construction of availability and performance maps for tracking concentrators. Although the following maps are at best only rough sketches of expected annual direct normal radiation, we believe they represent an important first step in the presentation of technical/economic analyses in an easily comprehended form. Figure $\mathrm{A}-1$ shows the average annual direct normal insolation for each SOLMET site. Contours for direct normal insolation were mapped by season in boes [AI]. These contour maps were overlaid in order to define the general trend of the contours, and then annual contours were drawn to fit the SOLMET values.

Annual deliverable heat contours, which are shown in Figures $\mathrm{A}-2$ to $A-7$, were derived from Figure $A-1$ by assuming an overall annual system operating efficiency which agrees with results of Sandia calculations in the Solar Total Energy System Testing Program. The annual efficiencies assumed are: 
Parabolic Dish

$1000^{\circ} \mathrm{F} \quad 51 \%$

$800^{\circ} \mathrm{F} \quad 58 \%$

$600^{\circ} \mathrm{F} \quad 64 \%$

$400^{\circ} \mathrm{F} \quad 69 \%$
Parabolic Trough

$600^{\circ} \mathrm{F} \quad 33 \%$

$400^{\circ} \mathrm{F} \quad 43 \%$

(Annual efficiency $=\frac{\text { Total deliverable heat from system }}{\text { Total annual direct normal insolation }}$ )

Figure A-8 shows the required annual deliverable heat (per square foot of collector) for a fuel-saving solar IPH system to meet the requirements of a $15 \%$ real after-tax rate of return on investment, with the following assumptions:

- General inflation at $5 \%$

- Fuel escalation (in real dollars) at $5 \%$

- 20-year accounting lifetime

- Sum-of-the-years-digits depreciation

- Investment tax credit of $10 \%$

- OMRI as $2 \%$ of initial investment

- System costs of $\$ 30$ per square foot $\left(C_{\text {sys }}\right)$

- Displaced fuel costs of $\$ 5$ per delivered net MBtu in the first year of operation ( $p)$. Regional fuel costs are assigned according to the average 1977 regional price distribution for residual fuel oil.

The required annual deliverable heat is determined by setting the present worth PW (see Section VI of SERI-27) to zero and solving for $Q_{D e 1}$, given $P$ and $C_{\text {sys }}$. Specifically, for the assumptions outlined above, $\mathrm{PW}=0$ implies:

$$
6.4784 Q_{\text {Del }} P=0.8456 C_{\text {sys }}
$$




$$
Q_{\text {De } 1}=0.1305 \frac{C_{\text {sys }}}{P}
$$

Note that the required deliverable heat is directly proportional to system cost and inversely proportional to the initial price of fuel. It should also be noted that the factor of proportionality (e.g., 0.1305) is quite sensitive to the escalation rate for fuel and to the required rate of return on investment. For a real escalation rate of $1 \%$ for fuel, the factor of proportionality becomes 0.2533 ; and for the real escalation rate of $9 \%$, the fartor of proportionality becomes 0.0926 . Within this range, however, $Q_{\text {Del }}$ is more sensitive to proportional changes in $C_{s y s}$ or $p$ than to proportional changes in real fuel price escalation.

For example, Figure. A-9 shows the required deliverable heat for competitive solar IPH systems with the same set of assumptions as in the case illustrated in Figure $A-8$, but with $C_{\text {sys }}=\$ 15$ per square foot rather than $\$ 30$ per square foot. The potential competitiveness of solar process heat increases substantially. 


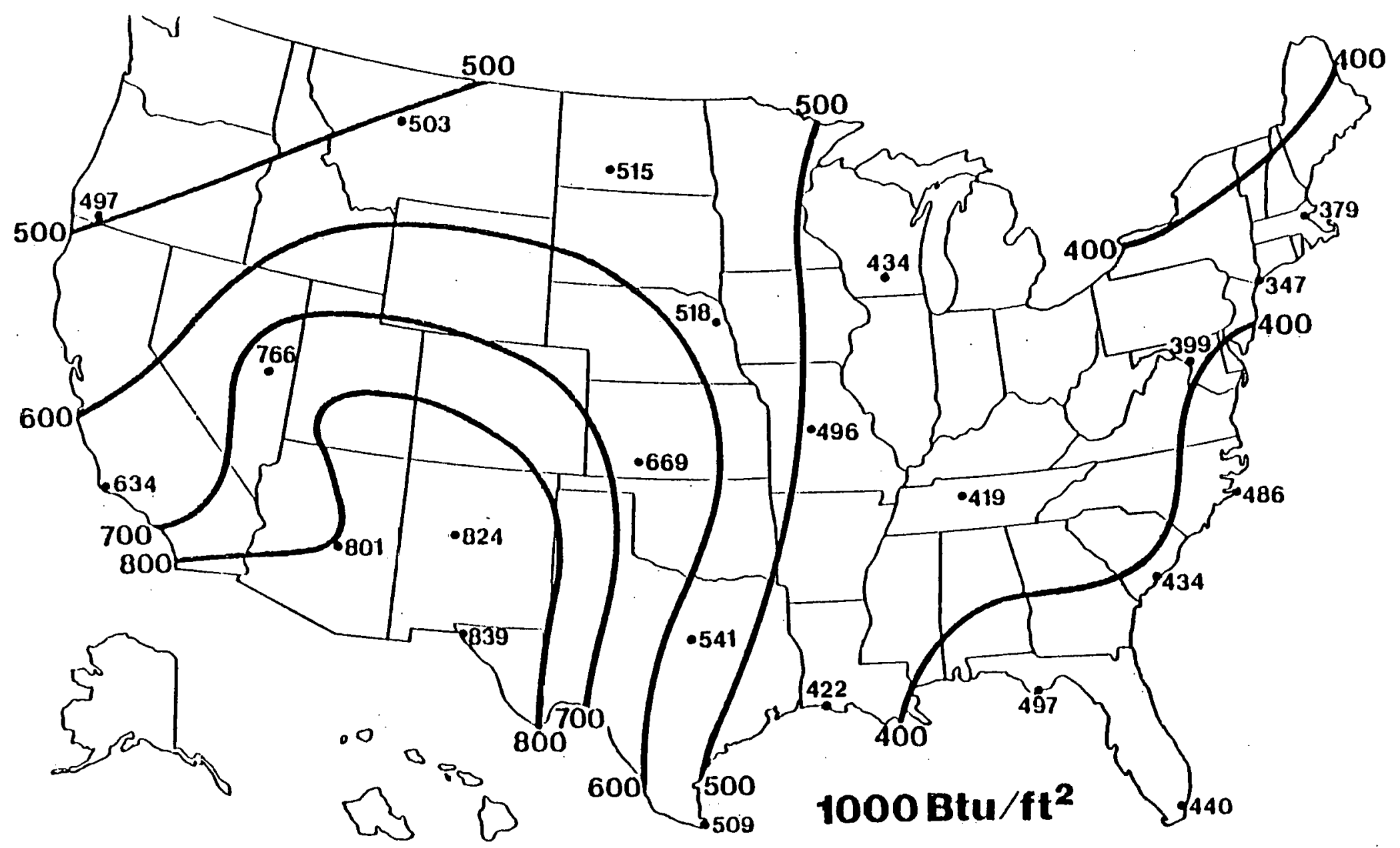

FIGURE 1 -1. AVERAGE ANNUAL. DIRECT NORMAL. INSOLATION (1000 BTU/FT'

(Rougli sketches from seasonal charts and revised SOLMET data

II SAND 77-08B5, "Availability of Direct, Total \& Diffuse

Solar Fadiation for Fixed and Tracking Collectors in the USA".

Rev. $1 / 30 / 78.1$ 


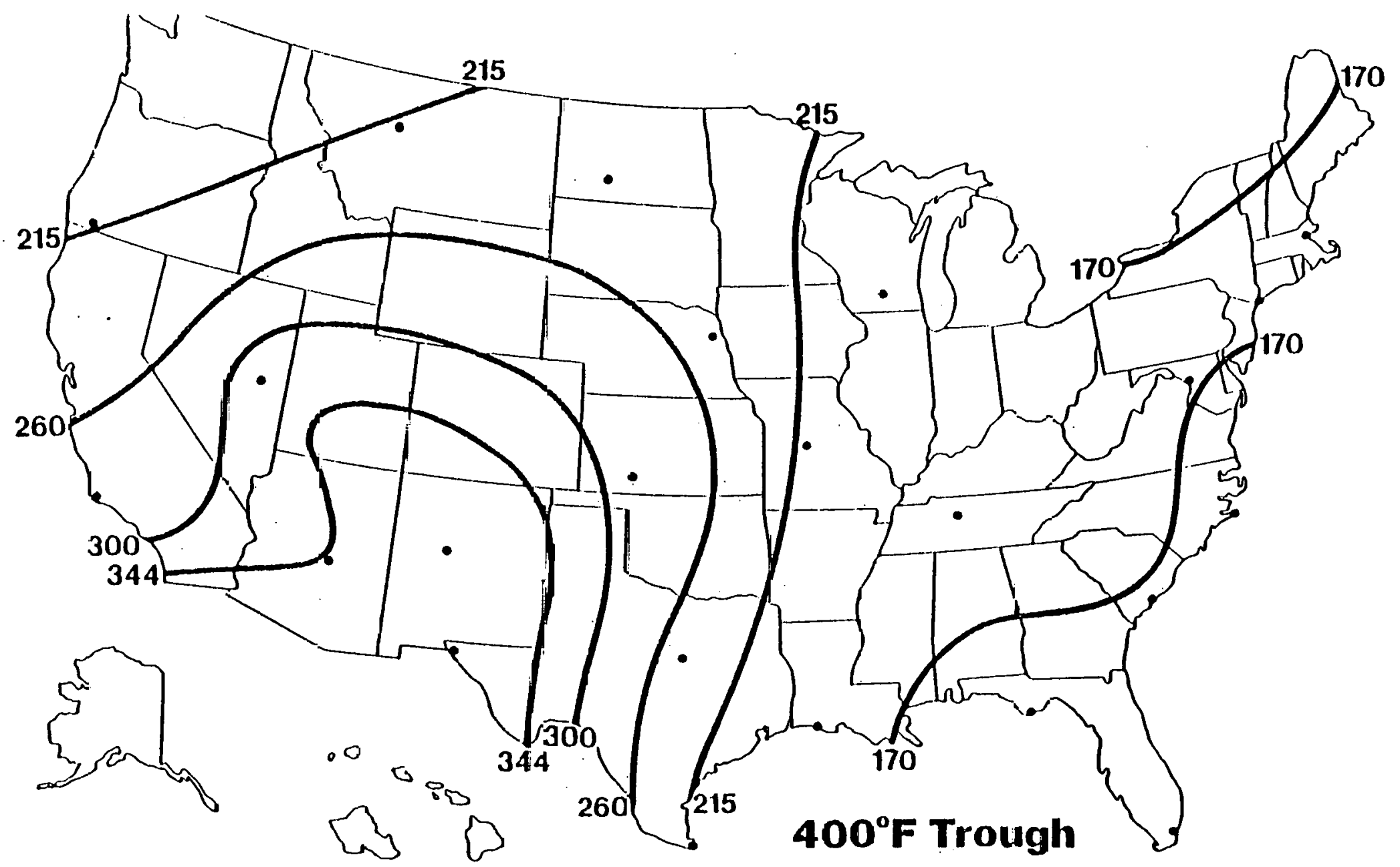

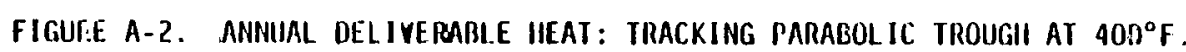
(1000 BTU/FT?) 


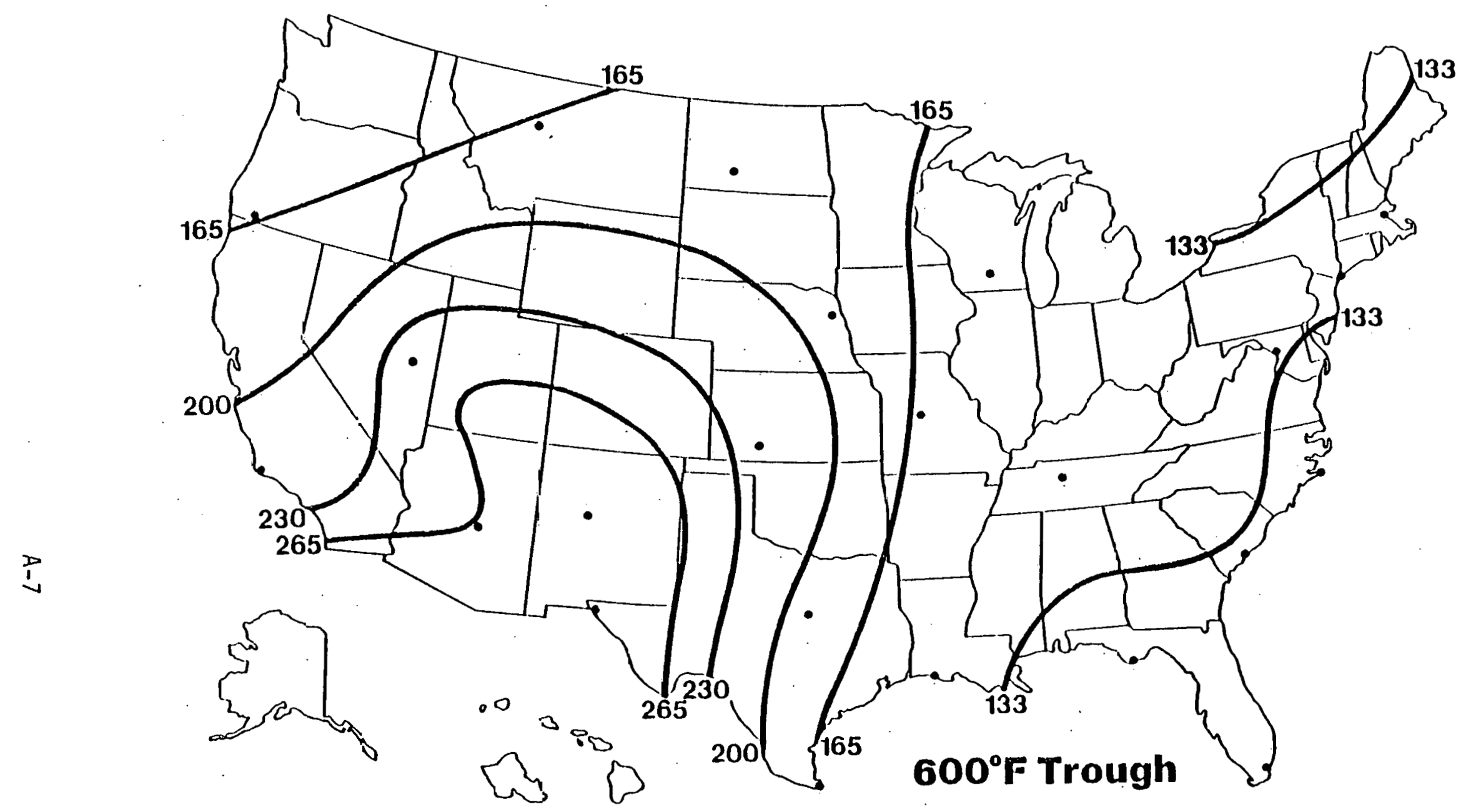

FIGURE A-3. ANHUAL DEL.IVERABLE HEAT: IRACKING PARABOLLIC TROUGII AT $600^{\circ} \mathrm{F}$. (1000 BTU/ $\left./ \mathrm{FT}^{2}\right)$ 


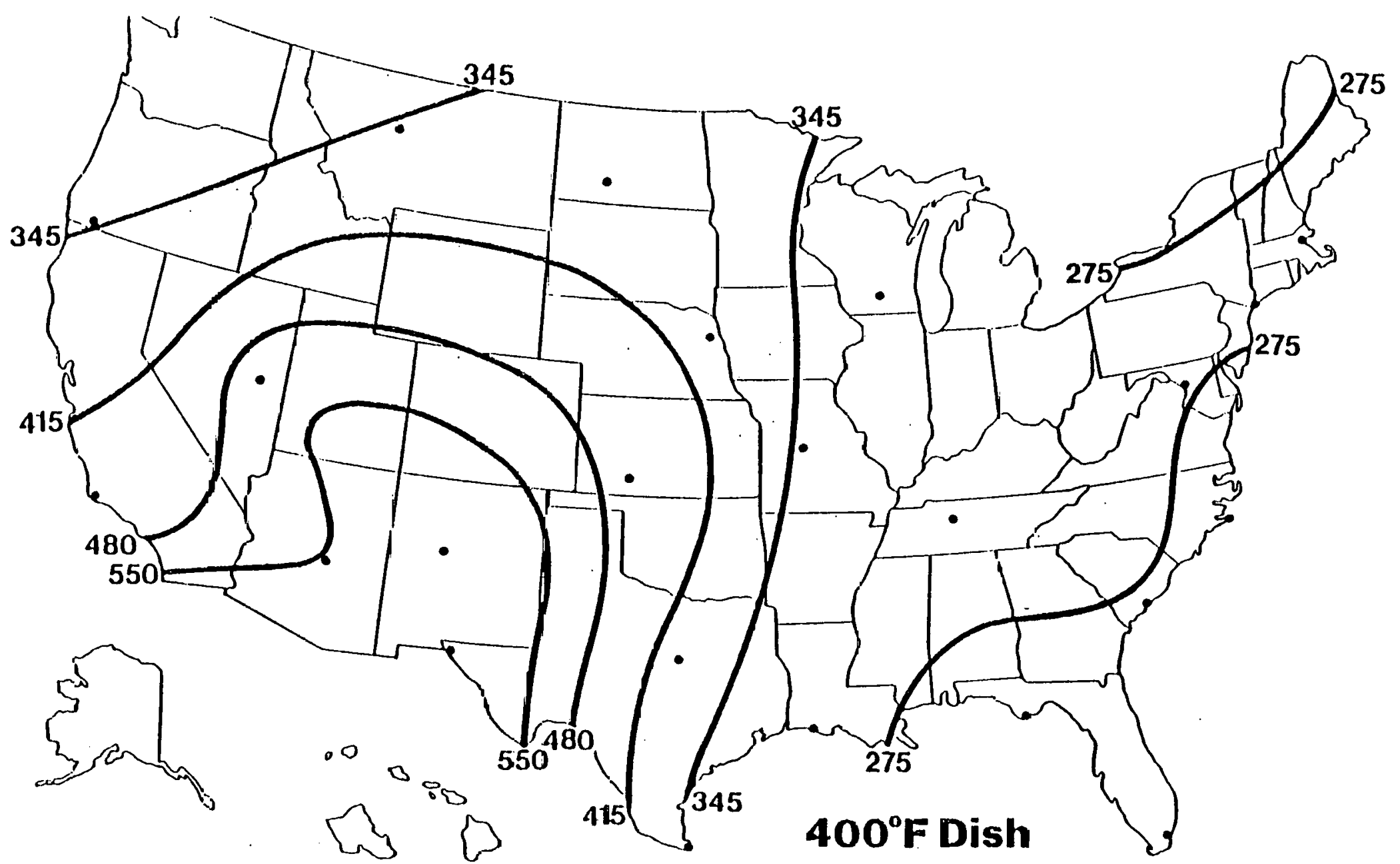

FIGURE A-A. AMNUAL. IFEL IVERAUI.E HEAT: DISTRIQUTED PARAGOLIC DISII AT $406^{\circ} \mathrm{F}$.

(1000 BTU/FT ${ }^{2}$ ) 


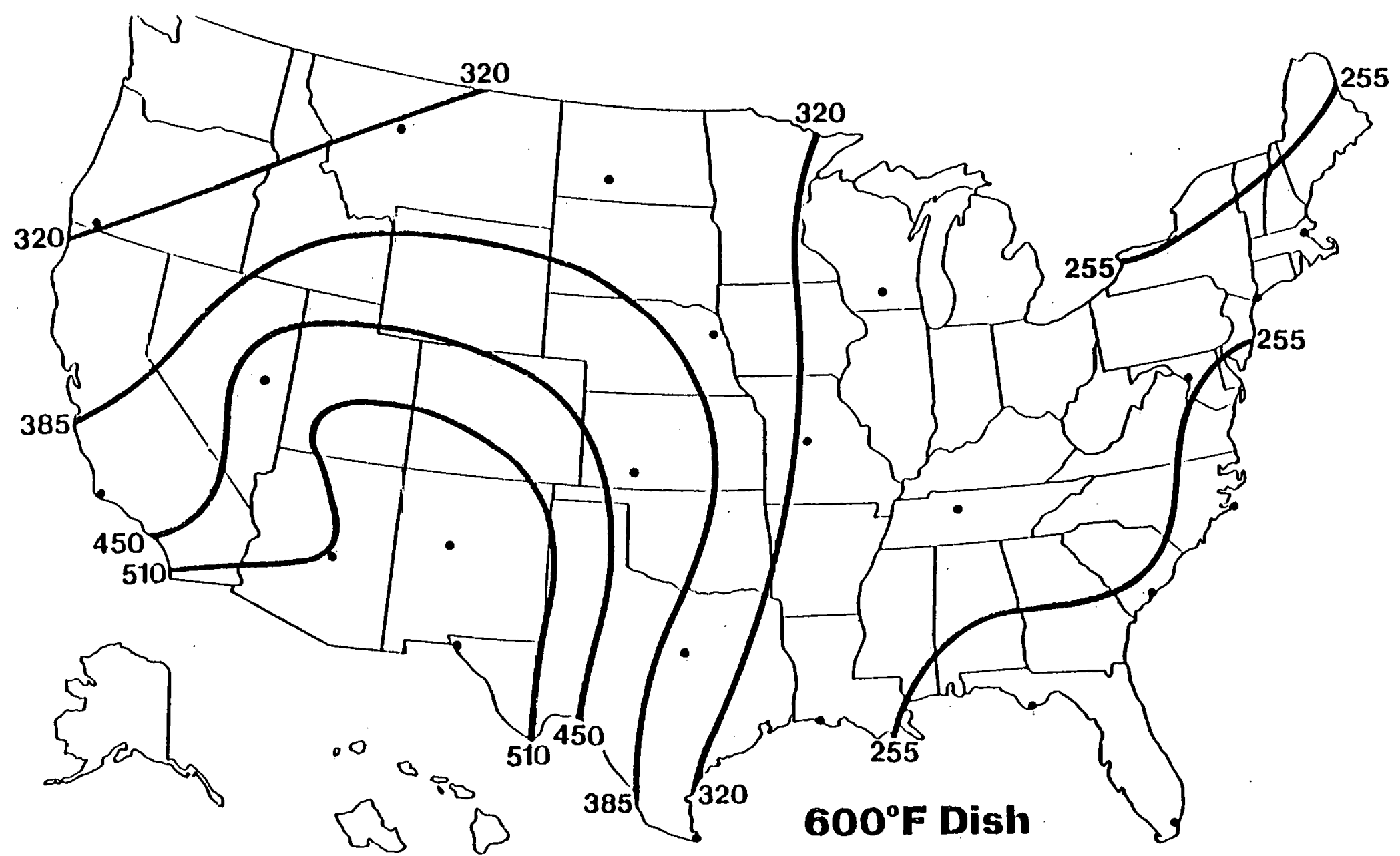

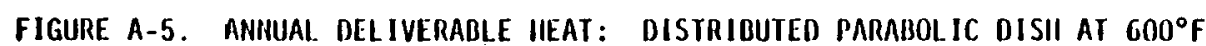
(1000 BTU/FT ${ }^{2}$ ) 


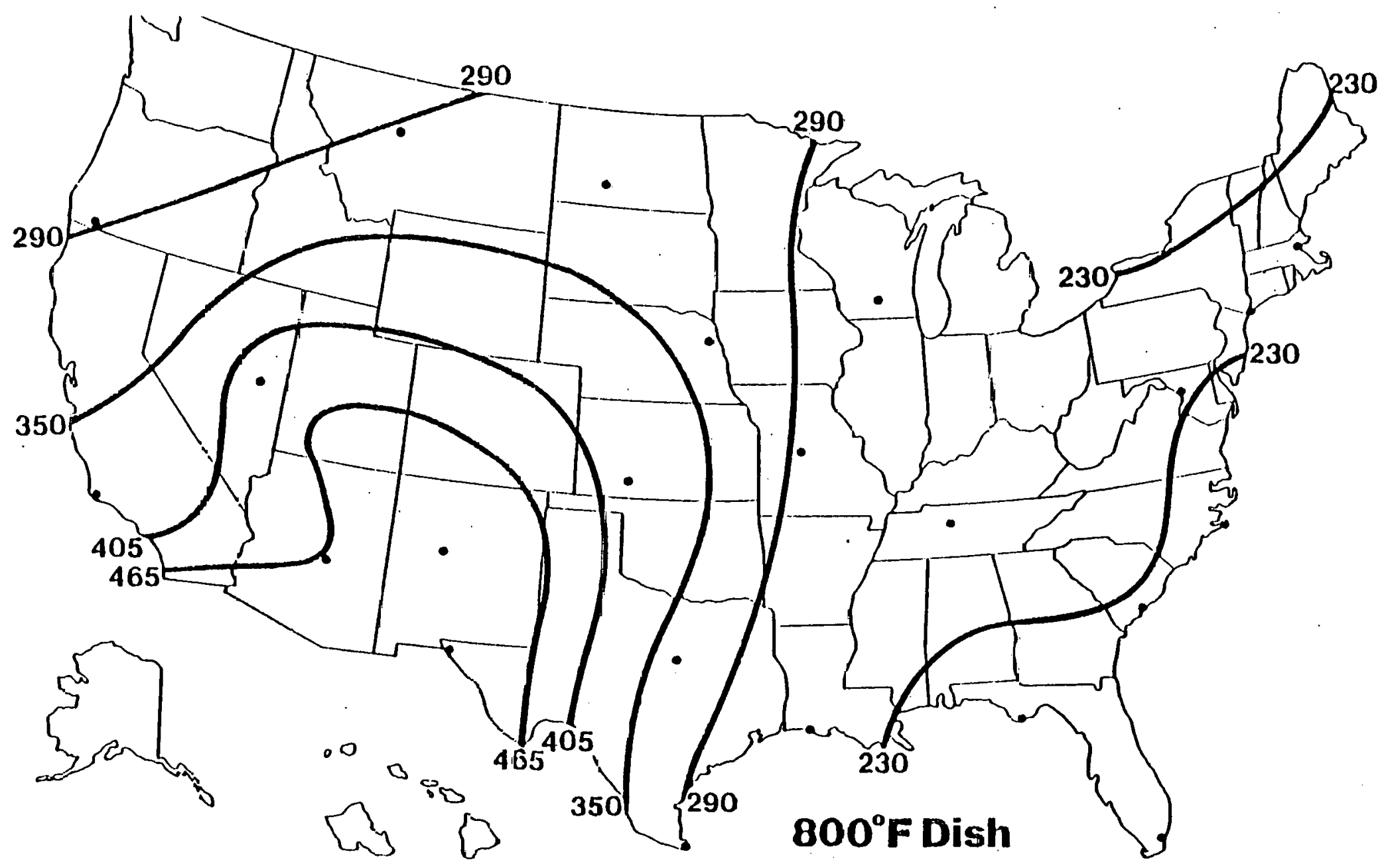

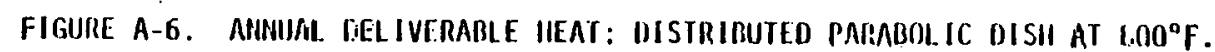

(1000 BTU/FT ${ }^{2}$ ) 


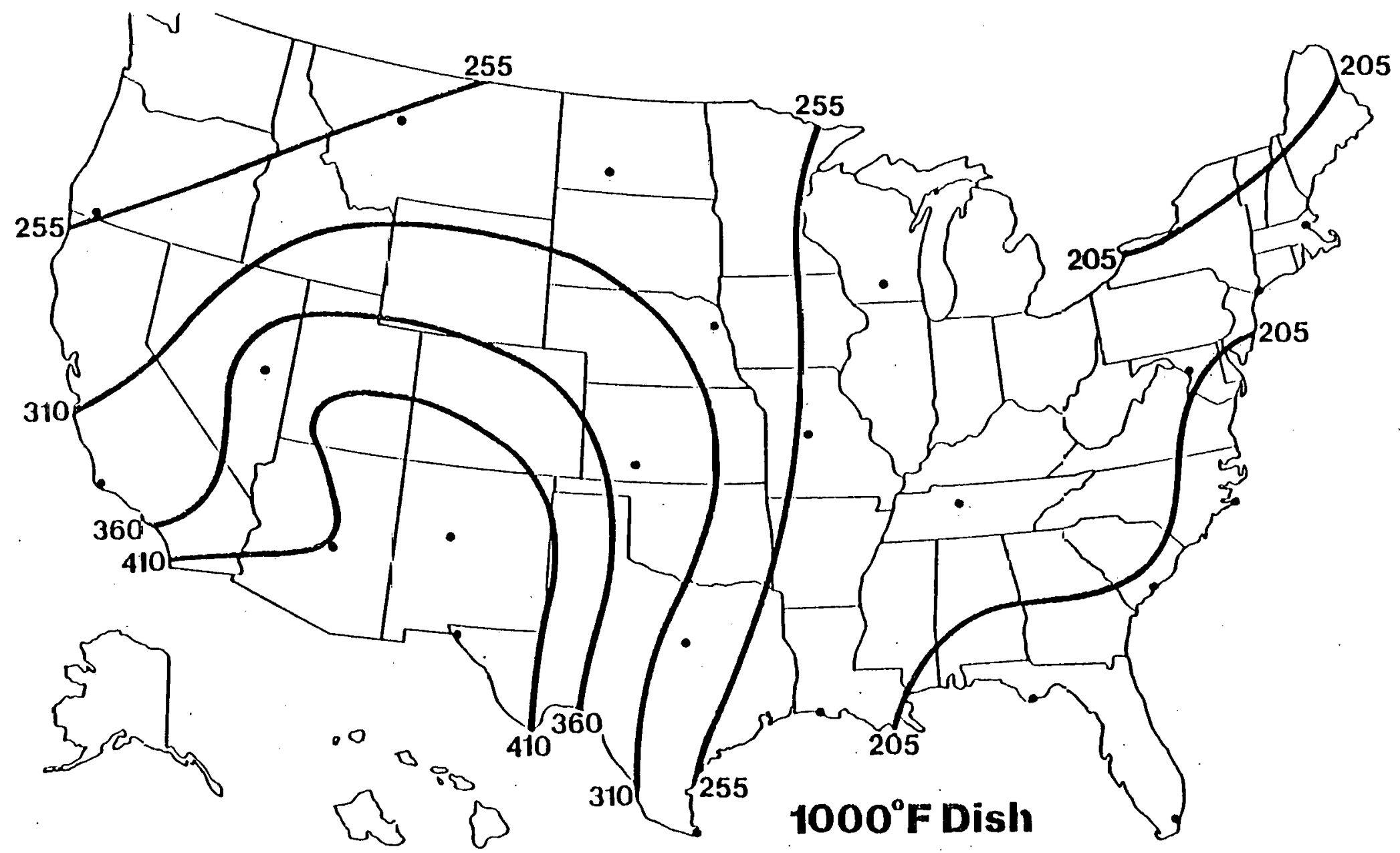

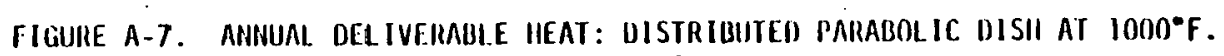
$\left(1000 \mathrm{OTU} / \mathrm{Fr}^{2}\right)$ 


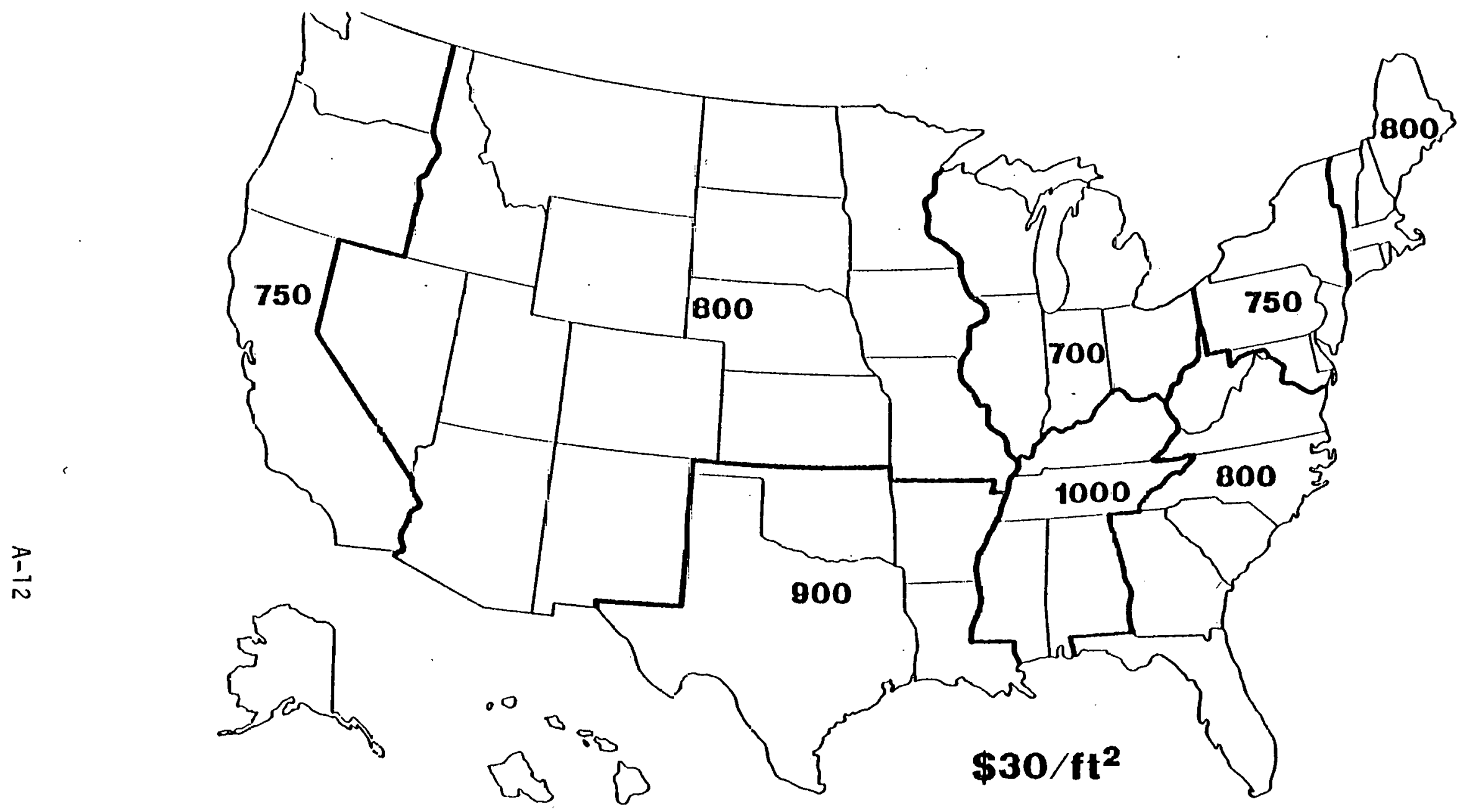

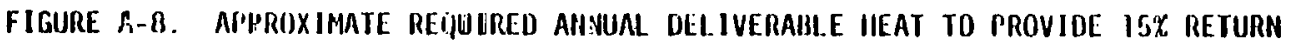
$\left(10.30 \mathrm{BTU} / \mathrm{FT}^{2}\right)$ 


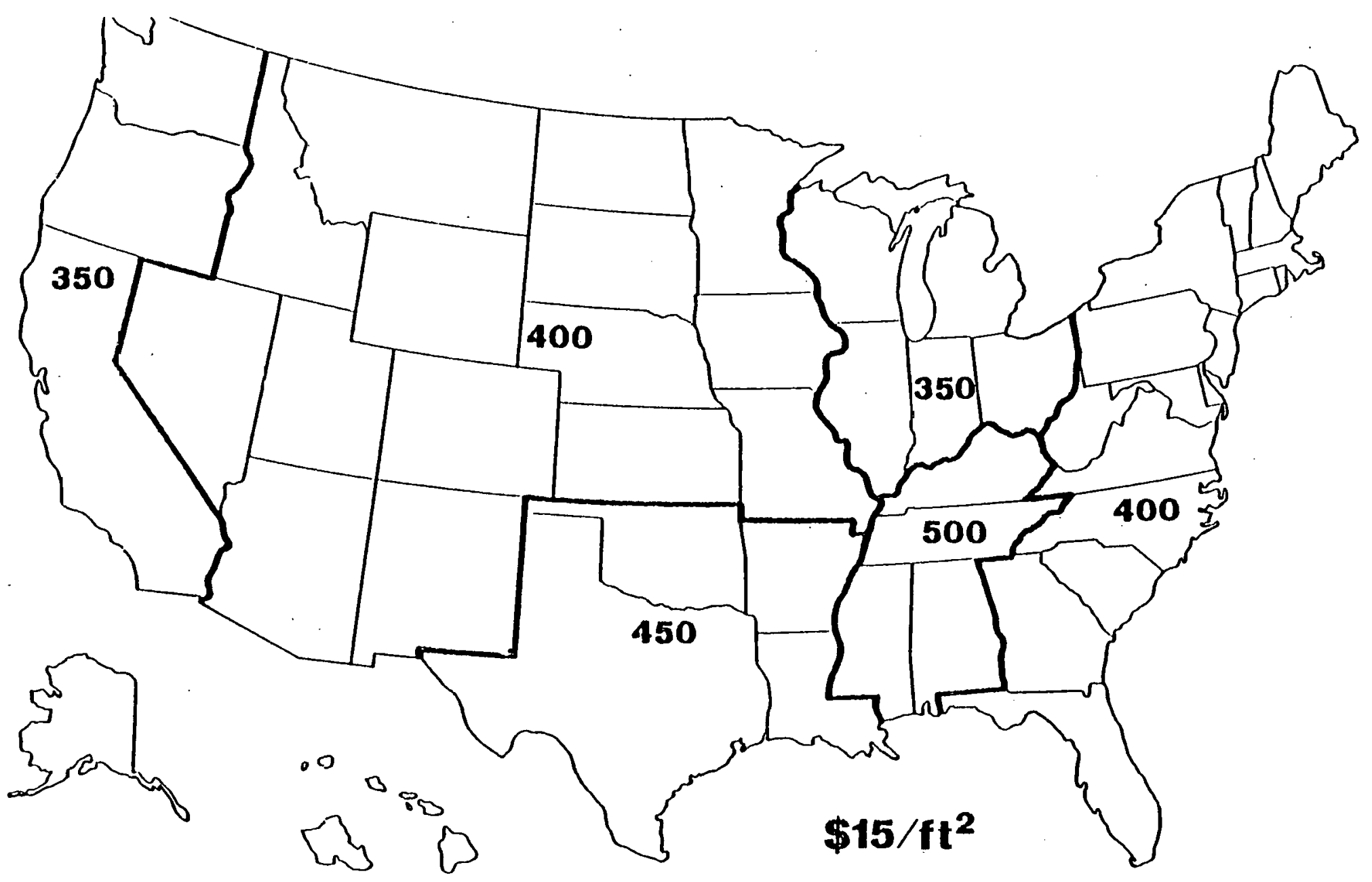

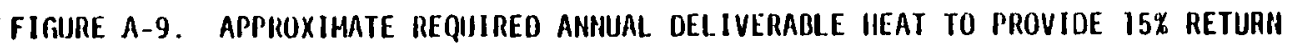
(1000 UTU/FT ${ }^{2}$ ) 


\section{APPENDIX REFERENCE}

Al. Boes, E. C., et al., "Availability of Direct, Tota1, and Diffuse Solar Radiation to Fixed and Tracking Collectors in the U.S.A.," SAND 77-0885, Albuquerque: Sandia Laboratories, August 1977, Revised January 30, 1978. 
№. of Copies

3

1

2

1

1

1

1

1

1
Distribution

Department of Energy

Chicago Operations Office

Attin: J. Kennedy

Division of Solar Technology office of Asst. Dir. for Administration

Attn: R. H. Annan

Office of Asst. Secretary for Conservation and Solar Applications

Attn: Ron Scott

On-site Representative

Attn: W. R. Cherry

Division of Solar Technology

Attn: H. H. Marvin

Division of Solar Technology Research and Development Branch Attn: M. Gutstein

Division of Solar Technology Office of Asst. Dir. for Thermal Power Systems Attn: G. W. Braun

Agricultural and Industrial Process Heat Branch

Attn: J. Dollard

Division of Solar Technology Dispersed Systems Branch

Attn: J. Rannels 